\title{
Sanaga Fault: Evidence of Neotectonics and Landscape Evolution in Edéa Region (Cameroon, Centre-Africa)
}

\author{
Augustin P. Moussango Ibohn' ${ }^{1}$, François Mvondo Owono², Bernard Njom³, Simon P. Mbog Bassong ${ }^{3}$, Jean-Paul \\ Sep Nlomngan ${ }^{3}$, Sébastien Owona ${ }^{2} \&$ Georges E. Ekodeck ${ }^{3}$ \\ ${ }^{1}$ Center for Geological and Mining Research, B.P. 333 Garoua, Cameroon \\ ${ }^{2}$ Department of Earth Sciences, University of Douala B.P. 24157 Douala, Cameroon \\ ${ }^{3}$ Faculty of Science, University of Yaoundé I, B.P. 812 Yaoundé, Cameroon \\ Correspondence: François Mvondo Owono, Department of Earth Science, University of Douala, B.P. 24157 \\ Douala, Cameroon. Tel: 237-696-691-543. E-mail: francois_mvondo@hotmail.com
}

Received: July 23, 2018

doi:10.5539/jgg.v10n3p57
Accepted: August 4, $2018 \quad$ Online Published: August 23, 2018

URL: http://dx.doi.org/10.5539/jgg.v10n3p57

\begin{abstract}
Morphometric parameters extracted from DEM $(90 \mathrm{~m})$ combined with field and literature data of Edéa region, a portion of Cameroonian passive margin located between $3^{\circ} 43^{\prime}-4^{\circ} 00$ ' $\mathrm{N}$ and $10^{\circ} 00^{\prime}-10^{\circ} 15^{\prime} \mathrm{E}$, were used to constraint the present day landscape and forces that have acted and is currently acting on its evolving topography. The obtained results show that the Sanaga Fault is one of the main driver forces responsible for this evolution. Set up during the Pan-African orogeny, this fault which affects a good part of the Proterozoic basement and Tertiary sedimentary cover has developed two systems of secondary active faults different by their nature and characteristics, quite visible in the Edéa region: the Ekitté System, shearing normal faults with a N-S to NNE-SSW strike and the Sanaga-Batignol System shearing directional faults with a NW-SE strike. Most of these faults constitute the river beds and play iteratively, deeply affecting both the drainage system and the landscape. Morphometric indices used reveal that the landscape has been rejuvenated and experiences uplifts and tiltings to present-day due to these reactivations. Structural and petrographical analyses confirm the current role played by the Sanaga Fault and its systems in the segmentation of the region into block tectonics and the occurrence of pseudotachylites and tectonic breccia. Block tectonics, pseudotachylites, tectonic breccias are accompanied with the recent earth tremors with magnitudes comprised between 2.6 and 4.0 on the Richter scale highlighting the neotectonics in this region.
\end{abstract}

Keywords: Block tectonics, Cameroon, Edéa region, Neotectonics, pseudotachylites, Sanaga Fault, Ekitté System

\section{Introduction}

The central and southern Cameroon is crossed by two major tectonic features: the Central Cameroon Shear Zone (CCSZ) to the North (Ngako et al., 2003), and the Sanaga Fault (SF) to the South (Dumont, 1986) (Figure 1).

The CCSZ is a ductile fault striking N70E that continues as far as the Gulf of Aden (Cornacchia \& Dars, 1983). This fault is also considered as a pre-drift extension of the Pernambuco fault in NE-Brazil (Louis, 1970; De Almeida et al., 1981). During the late Pan-African tectonic evolution, CCSZ was dextrally reactivated (Ngako et al., 1991).

The SF on the other hand, is a transcameroonian lithospheric lineament, lightly oblique which crosses the southern part of the country from the Gulf of Guinea to its border with the Centrafrican Republic where it relays the Bozoum-N'délé Fault at Bozoun (Cornacchia, 1980; Dumont, 1986). It corresponds to a major N70E lineament and covers a straight line distance of about $820 \mathrm{~km}$ along a fault axis zone of $100 \mathrm{~km}$. In Cameroon, the SF partly follows the direction of the Sanaga river and records post Pan-African reactivations (Ngangom, 1983). Since its identification by landsat remote sensing in the South of the CCSZ by Dumont (1986), few studies related to this sub-regional tectonic feature have been done. The works that exist have been done on a very large scale. They show that this fault is one of the major structures in Central Africa that strongly influences the evolution of the Cameroonian coastal sedimentary basins (Mvondo Owono, 2011; Djomeni et al., 2011; Koum et al., 2013). At local scale, the Lom mylonites are the only geologic evidence recorded for this fault (Soba, 1989). Many questions related to this accident are of utmost interest to geologists: (1) the age and the origin of the fault, (2) the effects of 
its reactivations on landscape evolution and (3) the relationship with seismicity.

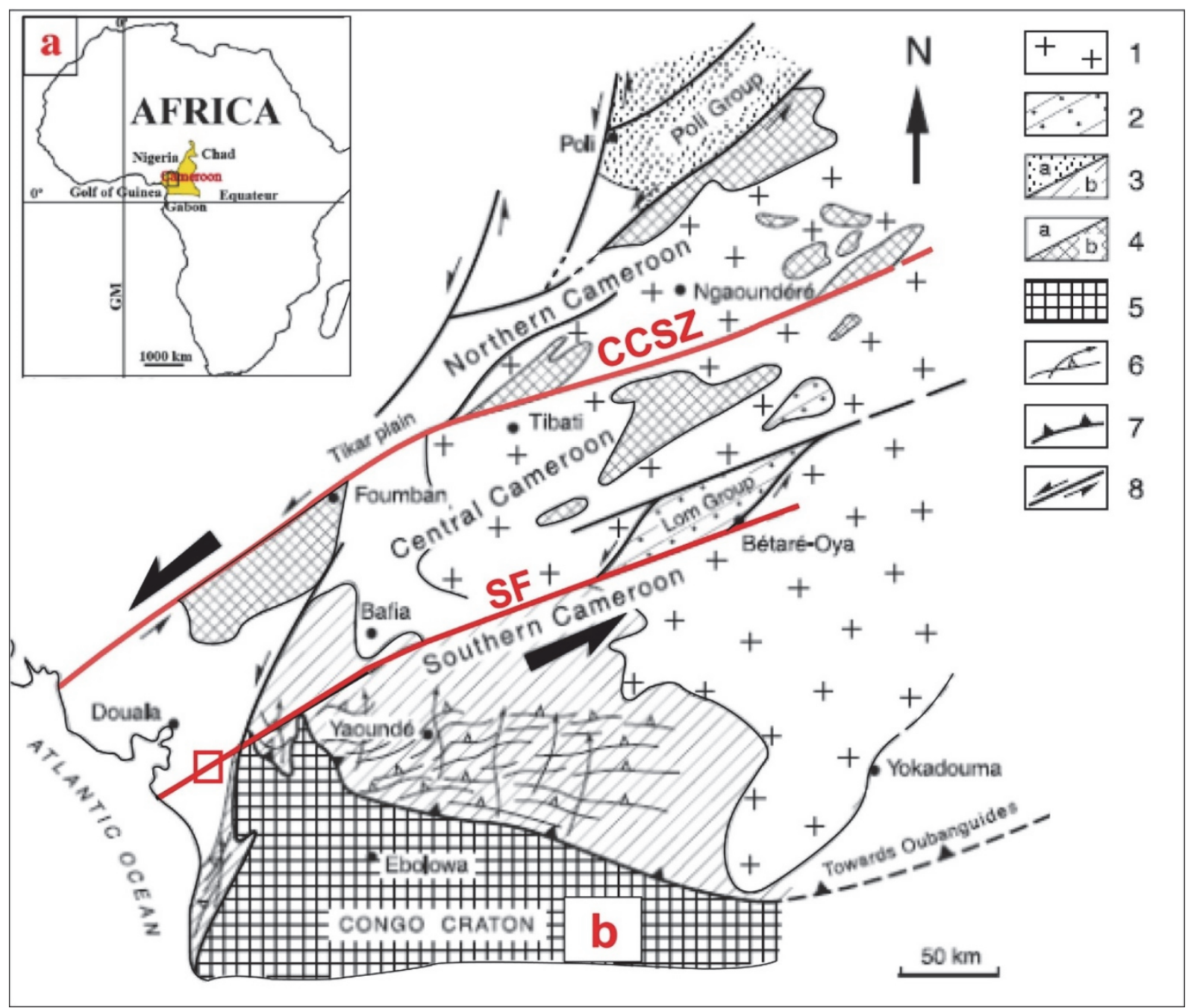

Figure 1. Location of the Cameroon coastal plain in Africa (a) and geological map of central and southern Cameroon showing the CCSZ and the SF (b). (1) syn-D2 granites; (2) Lom mylonites; (3a) Poli Group and (3b)

Yaoundé Group; (4a) undifferentiated gneisses and (4b) Eburnean basement relics; (5) Congo craton; (6) foliations $\mathrm{S}_{1-2}$ and stretching lineation's $\mathrm{L}_{2}$ (after Jegouzo, 1984); (7) major frontal thrust zone; (8) major shear zones, with indication of relative shear movement. The red box represents the study area

Using field data, geological maps 1:250 000 scale, Digital Elevation Model (DEM) and morphometric indices all crossed within ArcGIS, the present study focuses on Edéa region, between $3^{\circ} 43^{\prime}-4^{\circ} 00^{\prime} \mathrm{S}$ and $10^{\circ} 00^{\prime}-10^{\circ} 15^{\prime} \mathrm{E}$, aims to evaluate the tectonic control of the SF on Edéa landscape. Our hypothesis is that over this region, the reactivations of the SF have several consequences on the landscape evolution and its action is more prominent from late Tertiary to Quaternary. Then, our main objectives are: (1) evaluate the impact of this fault on drainage patterns and landscape from the analysis of morphometric indices, (2) analyse its relations with seismicity and (3) discuss its contribution to the neotectonics.

The choice of this part of the Cameroonian margin is based on the fact that a good part of the river flows on the fault. Thus, in addition to field data obtained from field surveys carried out in this region, we have the opportunity to better characterize the action of this fault in the Sanaga watershed through morphometric indices. These indices are measured on the rivers which constitute on field, the major elements capable of recording the least tectonic movements. Since, Bull and McFadden (1977), Burbank and Anderson (2001) have shown that the quantification of morphometric indices allows the determination of the interaction between tectonics and morphology in a given drainage basin, this study therefore becomes realistic. 


\section{Geological framework of the Edéa region}

The Edéa region is a portion of the Cameroonian passive margin located within the Gulf of Guinea. In this region, the SF affects two domains: a part of the Central African Fold Belt in Cameroon (CAFB) and a part of the Douala sub-basin (DSB).

The CAFB consists of the Nyong and Oubanguide complexes which constitute the basement overlapping by the Douala sub-basin formations (Figure 2). The Nyong Complex of palaeoproterozoic age (2400 - $1800 \mathrm{Ma})$ commonly known in this part of the country as the Nyong series is derived from the remobilization of the Congo craton during Eburnean orogeny (Penaye et al. 1993; Toteu et al. 1994; Ngako et al., 2006). It consists of syntectonic granitoids (augen orthogneiss and granitic orthogneiss) and pre to syn-tectonic granitoids (more or less migmatitic gneiss and charnockites). The Oubanguide Complex includes the Neoproterozoic formations (1600 $542 \mathrm{Ma}$ ) constituted of quartzites, amphibolites, micaschist and gneiss bearing garnet and kyanite. These proterozoic sets were respectively emplaced by the Pan African and the Eburnean orogenies, mainly characterised by three phases of deformation. The first two phases are ductile and composed of penetrative structures with a global NNE-SSW to NE-SW orientation. The last phase bears Pan African fractures with recent fault plays among which the Sanaga Fault. Geophysical studies realised in the Edéa region show two distinct structural provinces from either side of the Sanaga River: the north and the south provinces (Njiké Ngaha, 1984). They are separated by an important anomaly along the Sanaga river flow axis which corresponds to this fault.

The DSB occurred during the Aptian rifting which was associated to the opening of South Atlantic Ocean. It is comprised of conglomerates, coarse to fine sandstone, limestone, siltstone and marl deposited on Precambrian basement and differentiated in syn-rift formations from Barremian to Cenomanian and post-rift formations from Coniacian to Pleistocene (Nguene et al., 1992; Tamfu et al., 1995 and Oba, 2001) (Figure 3).

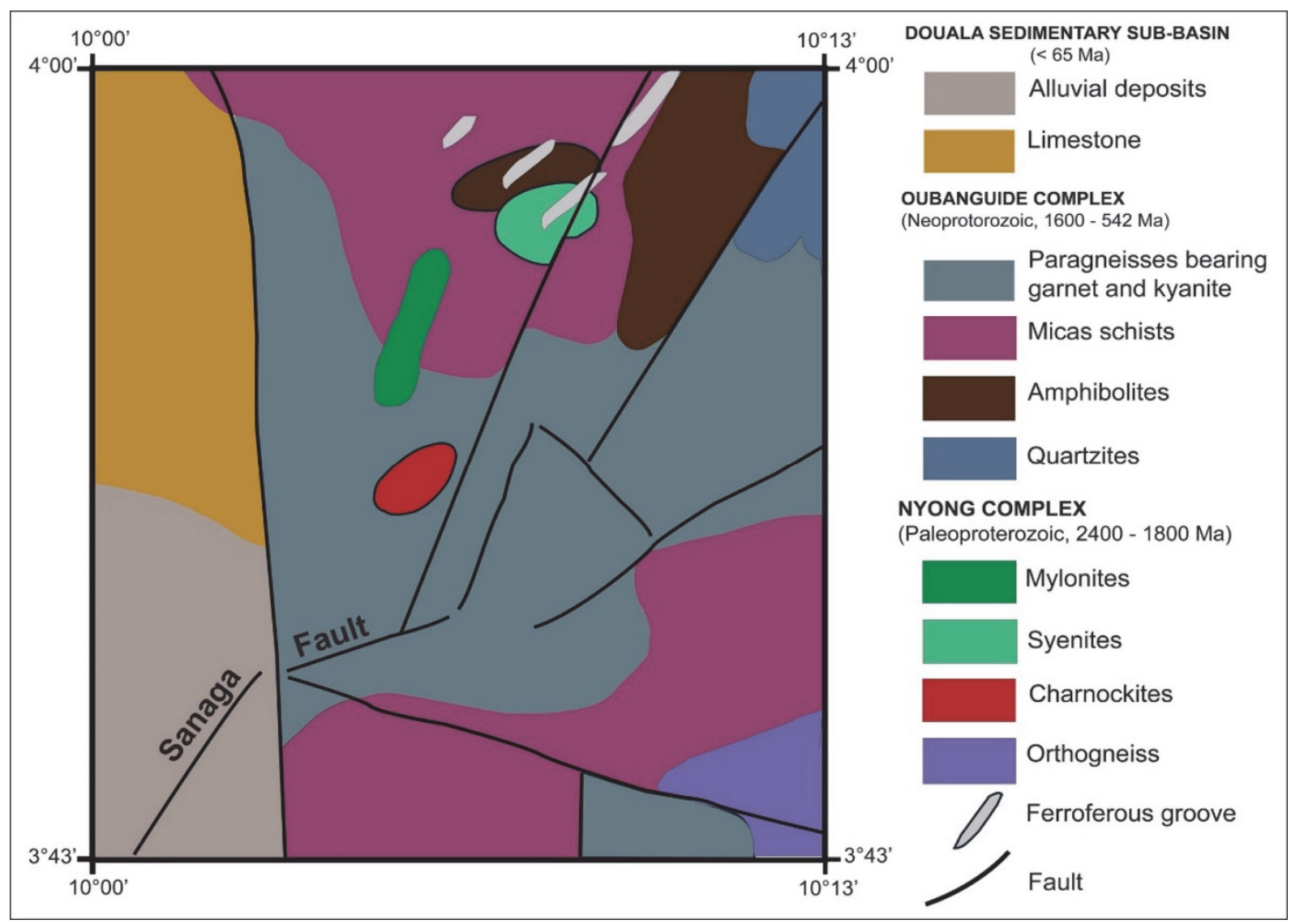

Figure 2. Geologic map of the study area 


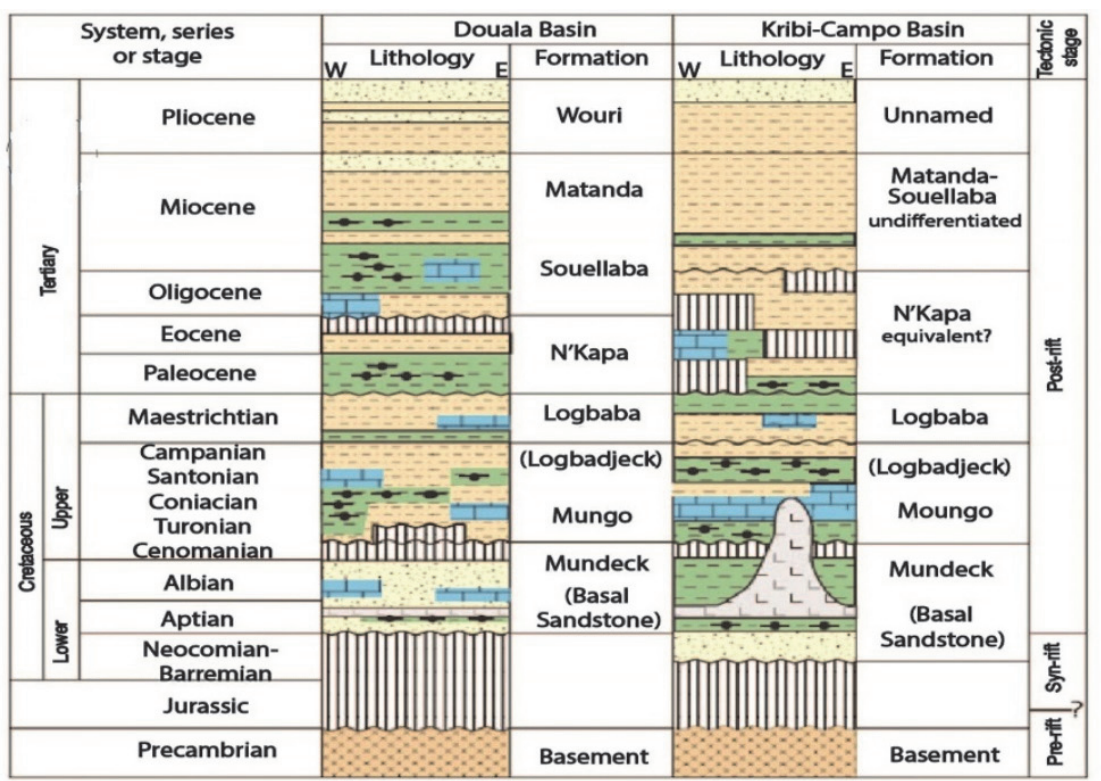

\section{EXPLANATION}

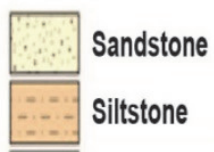

Shale

Organic-rich shale-

Potential source rocks

Limestone

Salt

Basement rocks

Missing or undrilled section

Unconformity

Figure 3. Chronolithostratigraphic column of Douala/Kribi-Campo basin showing sedimentary formations and tectonics phases, modified after Nguene et al. (1992), Tamfu et al. (1995) and Oba (2001).

\section{Materials and Methods}

Quantitative geomorphology based on morphometric analysis is used to deduce the effects of tectonics from morphometric indices. We make used SRTM-3 data to produce DEM. From the DEM, shade and hydrographical maps were automatically generated. These maps were used to describe, plot and compute some morphometric indices. Several morphometric indices were used. Table 1 summarizes the formulas and parameters used, the calculation or computation and the threshold values used for their interpretation.

Table 1. Mathematical relationships for the morphotectonic indices applied in this paper.

\begin{tabular}{|c|c|c|c|}
\hline $\mathbf{N}^{\circ}$ & Indices and authors & Formulae & Discussions \\
\hline 1 & $\begin{array}{l}\text { Hypsometric Integral } \\
\text { (HI) (Keller and Pinter, } \\
\text { 1996; Huertrez et al., } \\
\text { 1999; Chen et al., 2003) }\end{array}$ & $\begin{array}{l}\text { HI = (Hmean-Hmin)/ }(\mathbf{H m a x}-\mathbf{H m i n}) \\
\text { Hmean: Mean elevation, Hmin: } \\
\text { Minimum elevation, Hmax: Maximum } \\
\text { elevation, }\end{array}$ & $\begin{array}{l}\text { - } \mathrm{IH}>0.6 \text { defines young stages of basin } \\
\text { development with most of the topography } \\
\text { higher to the mean or an area with a very } \\
\text { high intensity of tectonic, reflecting recent } \\
\text { tectonics; } \\
0.3<\mathrm{IH}<0.6 \text { characterises mature basins, } \\
\text { extensive and long term erosion, } \\
\text { associated with dissected drainage basins; } \\
\text { - IH }<0.3 \text { indicates older basins, such as } \\
\text { peneplains. }\end{array}$ \\
\hline 2 & $\begin{array}{l}\text { Drainage density (Dd) } \\
\text { (Horton, 1945; Keller } \\
\text { and Pinter, 2002) }\end{array}$ & $\begin{array}{l}\mathbf{D d}=\boldsymbol{\Sigma} \mathbf{L i} / \mathbf{A} \\
\text { Li: Length of stream; A: Basin } \\
\text { area }\end{array}$ & $\begin{array}{l}\text { - The more a system is uplifting, the more } \\
\text { Dd decreases; } \\
\text { Basins with high values of Dd are } \\
\text { characteristic of ancient relief's very } \\
\text { prolonged exposure to the drainage; } \\
\text { - Low values of Dd are the particularity of } \\
\text { the regions affected by a recent tectonic } \\
\text { activity. }\end{array}$ \\
\hline 3 & $\begin{array}{l}\text { Drainage basin } \\
\text { asymmetry factor (AF) } \\
(\mathrm{Cox}, 1994)\end{array}$ & $\begin{array}{l}\mathrm{AF}=(\mathrm{Ar} / \mathrm{At}) 100 \\
\text { Ar: Area of the basin to the right of the }\end{array}$ & $\begin{array}{l}\text { AF close to } 50 \text {, shows no or a slight tilting } \\
\text { perpendicular to the direction of the trunk } \\
\text { channel; } \\
\text { AF above or below } 50 \text {, has inferred the }\end{array}$ \\
\hline
\end{tabular}




\begin{tabular}{|c|c|c|c|}
\hline & & $\begin{array}{l}\text { trunk stream; At: Total area of the } \\
\text { drainage basin, }\end{array}$ & $\begin{array}{l}\text { significant tilting of drainage basin, due to } \\
\text { either active tectonics or lithologic control. }\end{array}$ \\
\hline 4 & $\begin{array}{l}\text { Transverse topographic } \\
\text { symmetry factor (TTSF) } \\
(\text { Cox, 1994) }\end{array}$ & $\begin{array}{l}\text { TTSF }=\text { Da / Dd } \\
\text { Da: Distance from midline of the } \\
\text { drainage basin to the midline of the } \\
\text { river; Dd: Distance from the basin } \\
\text { midline to the basin divide. }\end{array}$ & $\begin{array}{l}\text { - TTSF }<0.5: \text { the drainage basin is } \\
\text { influenced by the tilting of the terrain due } \\
\text { to tectonic activity; } \\
\text { - TTSF }>0.5: \text { the tilting does not have an } \\
\text { influence on the drainage. }\end{array}$ \\
\hline 5 & $\begin{array}{lrr}\text { Concavity } & \text { Index } & \text { (IC) } \\
\text { (Snow } & \& \\
\text { Slingerland } & , 1987 ; \\
\text { Rhea,1993) } & \end{array}$ & $\begin{array}{l}\text { IC }=2 \mathbf{A} / \mathbf{H} \\
\text { A: Difference of altitude between the } \\
\text { middle profile and a straight line } \\
\text { joining the two ends of the profile; } \mathrm{H}: \\
\text { Difference in height between the } \\
\text { channel head and the outlet. }\end{array}$ & $\begin{array}{l}\text { IC } \sim 0 \text { : the form of the profile is close to } \\
\text { a straight line; } \\
\text { IC }<0 \text { : the form of profile shows } \\
\text { convexo-concave trend; } \\
\text { IC }>0 \text { : the form of profile indicates the } \\
\text { concave trend. }\end{array}$ \\
\hline 6 & $\begin{array}{l}\text { Valley floor width to } \\
\text { valley height ratio (VF) } \\
\text { (Bull \& McFadden } \\
\text { 1977; Burbank \& } \\
\text { Anderson 2001; Keller } \\
\text { \& Pinter 2002) }\end{array}$ & $\begin{array}{l}\mathbf{V F}=\mathbf{2 V f w} /((\text { Eld }- \text { Esc })+(\text { Erd }- \text { Esc })) \\
\text { Vfw: Width of the valley floor; Eld and } \\
\text { Esc: Elevations of the left and right } \\
\text { valley divides. }\end{array}$ & $\begin{array}{l}\text { - } \mathrm{VF}>1 \text { : broad valleys and low uplift } \\
\text { rates; } \\
\text { - } \mathrm{VF}<1 \text { : V-shaped valleys, actively } \\
\text { incising and high uplift rates. }\end{array}$ \\
\hline 7 & $\begin{array}{l}\text { Longitudinal profile } \\
\text { (Mvondo Owono, } 2011 \\
\text { and Mvondo Owono } \\
\text { et al., 2016) }\end{array}$ & $\begin{array}{l}\text { AN=Am }+[((\mathbf{A H}-\mathbf{A L}) /(\operatorname{LogLm}- \\
\operatorname{LogLM})) *(\operatorname{LogLi}-\log \mathbf{L M})] \\
\text { AN: Equilibrium normalised altitude } \\
\text { value; AH and AL: Highest and lowest } \\
\text { altitude; LM and Lm: maximum and } \\
\text { minimum length; Li: Length value } \\
\text { calculated for each considerate point in } \\
\text { relation with the upstream. }\end{array}$ & $\begin{array}{l}\text { - Concave longitudinal profiles are } \\
\text { characterise old rivers, in equilibrium } \\
\text { state; } \\
\text { - Convex longitudinal profiles are } \\
\text { characteristics of young river or old } \\
\text { rivers reactivated by fault or affected by } \\
\text { uplift. }\end{array}$ \\
\hline 8 & $\begin{array}{l}\text { Stream-length index } \\
\text { (SL) (Keller and Pinter, } \\
\text { 2002; Zhang et al., 2011; } \\
\text { Dar et al., 2014) }\end{array}$ & $\begin{array}{l}\qquad \mathbf{S L}=\Delta \mathbf{H} / \Delta \mathbf{L} \mathbf{L}^{*} \mathbf{L} \\
\Delta \mathrm{H}: \text { Difference in elevation between the } \\
\text { ends of the considered reach; } \Delta \mathrm{l} \text { : Length } \\
\text { of the reach; L: Distance between the } \\
\text { measured reach and the drainage divide. }\end{array}$ & $\begin{array}{l}\text { Very high or very low SL values reveal } \\
\text { tectonic distortions if there is no correlation } \\
\text { with lithologic factors }\end{array}$ \\
\hline 9 & $\begin{array}{l}\text { Deviation (D) } \\
\text { (Goldrick and Bishop, } \\
\text { 1995; Larue, 2008, } \\
\text { Ambili, 2010). }\end{array}$ & $\begin{array}{l}\text { The amount of deviation was measured } \\
\text { by the projection of the upstream } \\
\text { equilibrium profile and subtraction of } \\
\text { the actual stream elevation from the } \\
\text { projected elevation. }\end{array}$ & $\begin{array}{l}\text { High values of } D \text { indicate an imbalance caused } \\
\text { by lowering basal level, tectonics and } \\
\text { lithology on which the water flows or the } \\
\text { decline in the base level. }\end{array}$ \\
\hline
\end{tabular}

Structural and petrographic analyses supported by literature, field observations and geological maps in 1:250 000 scale and quantitative geomorphology on DEM, all crossed within ArcGis, a GIS software, constitute the main approaches used in this study to depict the tectonic control on Edéa landscape.

Field work included the description of the different outcrops, structural measurements, and collection of samples. Petrographical approach concerns particularly mesoscopic and microscopic analyses of tectonic rocks while structural analysis was carried out on the realization of density and rose diagrams of tectonic structures.

\section{Results}

\subsection{Landform Analysis}

The combined analysis of the DEM and hillshade map (Figure 4), shows that Edéa region is a lowland plateau belonging to the coast with relief that varies between 0 and $564 \mathrm{~m}$. The altitude increases from the coast to the East and to the North, where it becomes elongated. Its ice-smoothment, already reported at a regional scale represents the alternation of high reliefs corresponding to horsts in the Nord and low reliefs corresponding to grabens to the South. Certain limits of these units are active faults. The study area displays three morphological units with variable altitudes (Figure 4, Table 2). 


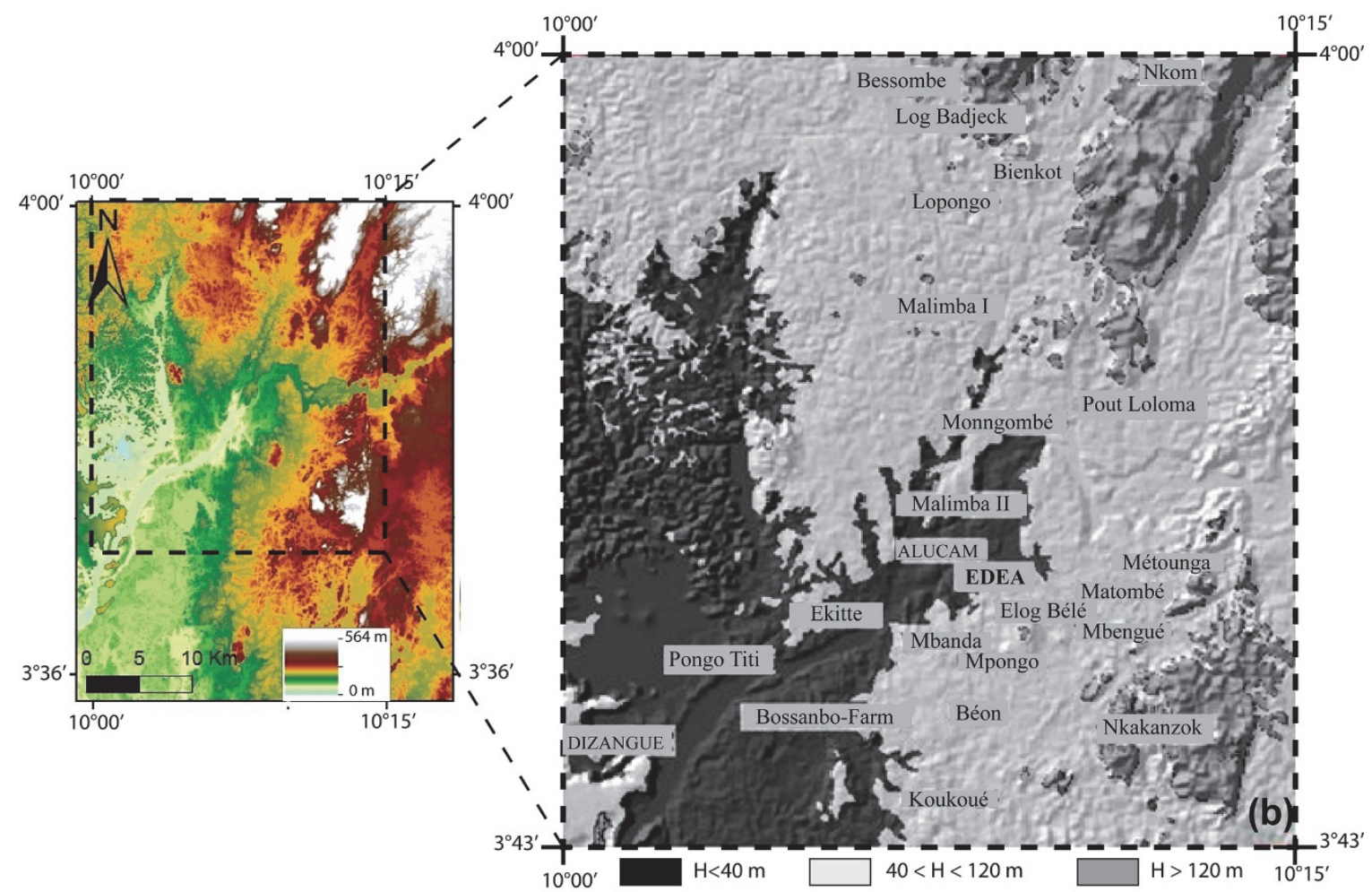

Figure 4. DEM (a) and Hillshade map (b) of the study area showing three main morphological units. Note that the relief becomes higher and elongated to the North and West of the region.

Table 2. Major geomorphic units of the Edéa region with the physiographic condition and a real coverage

\begin{tabular}{|c|c|c|c|}
\hline $\begin{array}{l}\text { Geomorphic } \\
\text { units }\end{array}$ & $\begin{array}{l}\text { Range of } \\
\text { contour }(\mathrm{m})\end{array}$ & Physiography character & $\begin{array}{l}\text { Area } \\
(\%)\end{array}$ \\
\hline $\begin{array}{lll}\text { Unit } 1: & \text { High } \\
\text { reliefs }\end{array}$ & $>120$ & $\begin{array}{l}\text { Very undulating part with several residual hills; very hard rock } \\
\text { with igneous intrusion }\end{array}$ & 10 \\
\hline $\begin{array}{l}\text { Unit 2: moderate } \\
\text { reliefs }\end{array}$ & $40-120$ & $\begin{array}{l}\text { Dissected by wide and few deep river valleys; moderate slope } \\
\text { in the east, moderate to hard rock; gentle slope to the Nord and } \\
\text { NW; }\end{array}$ & 25 \\
\hline 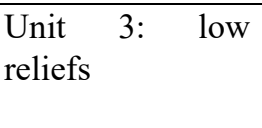 & $<40$ & $\begin{array}{l}\text { Steep rising slope in the western margin; very incised by the } \\
\text { Sanaga River; wide and narrow river valley; moderate to soft } \\
\text { rock. }\end{array}$ & 65 \\
\hline
\end{tabular}

The hydrographic network includes three main collectors: the Sanaga River, the Mevia and Ossa endoreic lakes (Figure 5). The drainage pattern is mainly dendritic with rectangular, elongated and sub-parallel tendencies for the Sanaga river; dissymmetric one for the Mevia and Ossa lakes. The main flow directions and senses are summarized on the table 3. These pattern tendencies suggest the existence of lithological heterogeneities of the substratum while their pluri-kilometric rectilinear streams may be associated to fractures. Otherwise, the drainage network is marked by a zone of criss-cross and braided network in the Edéa town.

Table3. Hydrographical patterns and flow directions and senses.

\begin{tabular}{lllll}
\hline \multirow{2}{*}{ Watershed } & \multicolumn{2}{l}{ River patterns. } & \multicolumn{2}{l}{ Flow directions and senses of streams } \\
\cline { 2 - 5 } & Main & Secondaries & Major & Secondaries \\
\hline \multirow{2}{*}{ Sanaga } & Dendritic & Rectangular, subparallel and elongate & $\mathrm{N} \rightarrow \mathrm{S}$ & $\mathrm{W} \rightarrow \mathrm{E}$ \\
& & & $\mathrm{NNE} \rightarrow \mathrm{SSW}$ & $\mathrm{NE} \rightarrow \mathrm{SW}$ \\
\multirow{2}{*}{ Mevia lake } & Dendritic & Elongate & $\mathrm{N} \rightarrow \mathrm{S}$ & $\mathrm{E} \rightarrow \mathrm{W}$ \\
& & & & $\mathrm{W} \rightarrow \mathrm{E}$
\end{tabular}


$\begin{array}{lll}\text { Ossa lake Dendritic Elongate } & \mathrm{NE} \rightarrow \mathrm{SW}\end{array}$

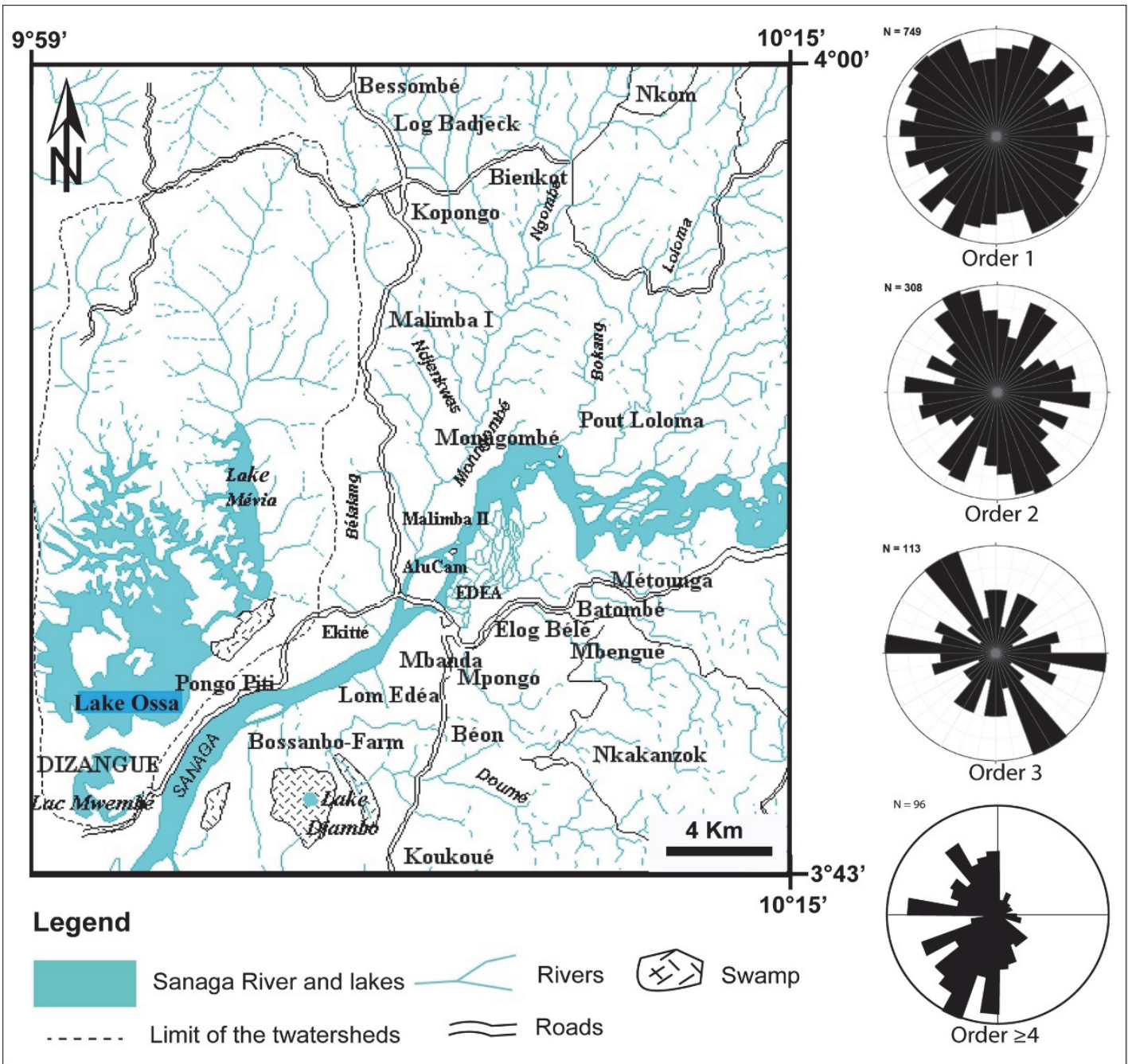

Figure 5. Hydrographical network of the Edea area extracted from DEM) and rose diagrams of rectilinear river sections of streams per order showing the main flow directions.

\subsection{Morphometric Analysis}

In order to characterize the impact of the SF on the Edéa landscape, we used several morphometric indices. Some of them are summarized in table 4 below.

Table 4. Rivers characteristics of the study area

\begin{tabular}{llllllllll}
\hline Tributaries & $\mathrm{L}(\mathrm{km})$ & $\mathrm{E}(\mathrm{m})$ & $\mathrm{S}(\mathrm{m} / \mathrm{km})$ & $\mathrm{IC}$ & $\mathrm{D}(\mathrm{m})$ & $\mathrm{P}(\mathrm{km})$ & $\mathrm{A}\left(\mathrm{km}^{2}\right)$ & $\mathrm{Dd}$ & $\mathrm{HI}$ \\
\hline Ndjeke & 169.68 & 939 & 5.53 & 0.3 & 325 & 476.14 & 4434.5 & $/$ & 0.17 \\
Téré & 61.94 & 704 & 11.37 & 0.1 & 127 & 196.54 & 832.06 & $/$ & 0.35 \\
Yong & 96.16 & 699 & 7.27 & 0.016 & 70 & 383.38 & 2700.57 & $/$ & 0.48 \\
Sanaga & 582.78 & 654 & 1.12 & -0.34 & 628 & 2852 & 81128.97 & 0.22 & 0.28 \\
Mbam & 316.97 & 890 & 2.81 & -0.02 & 458 & 1246.35 & 26591.58 & $/$ & 0.22 \\
Djérem & 145.26 & 774 & 5.33 & 0.12 & 122 & 561.92 & 6229.54 & $/$ & 0.3 \\
Lom & 209.14 & 854 & 4.08 & 0.18 & 176 & 619.34 & 8844.38 & $/$ & 0.36 \\
\hline
\end{tabular}

L: Length; E: Elevation of the source; S: Slope; IC: Concavity Index; D: Deviation; P: Perimeter; A: Area; Dd: Drainage density; IH: Integral Hypsometry. 


\subsubsection{Hypsometric Curves and Hypsometric Integral (HI)}

The Sanaga basin consists of 7 sub-basins: Sanaga, Djérem, Lom, Mbam, Ndjeke, Téré and Yong with variable areas, the largest being that of the Sanaga (Table 4, Figure 6).

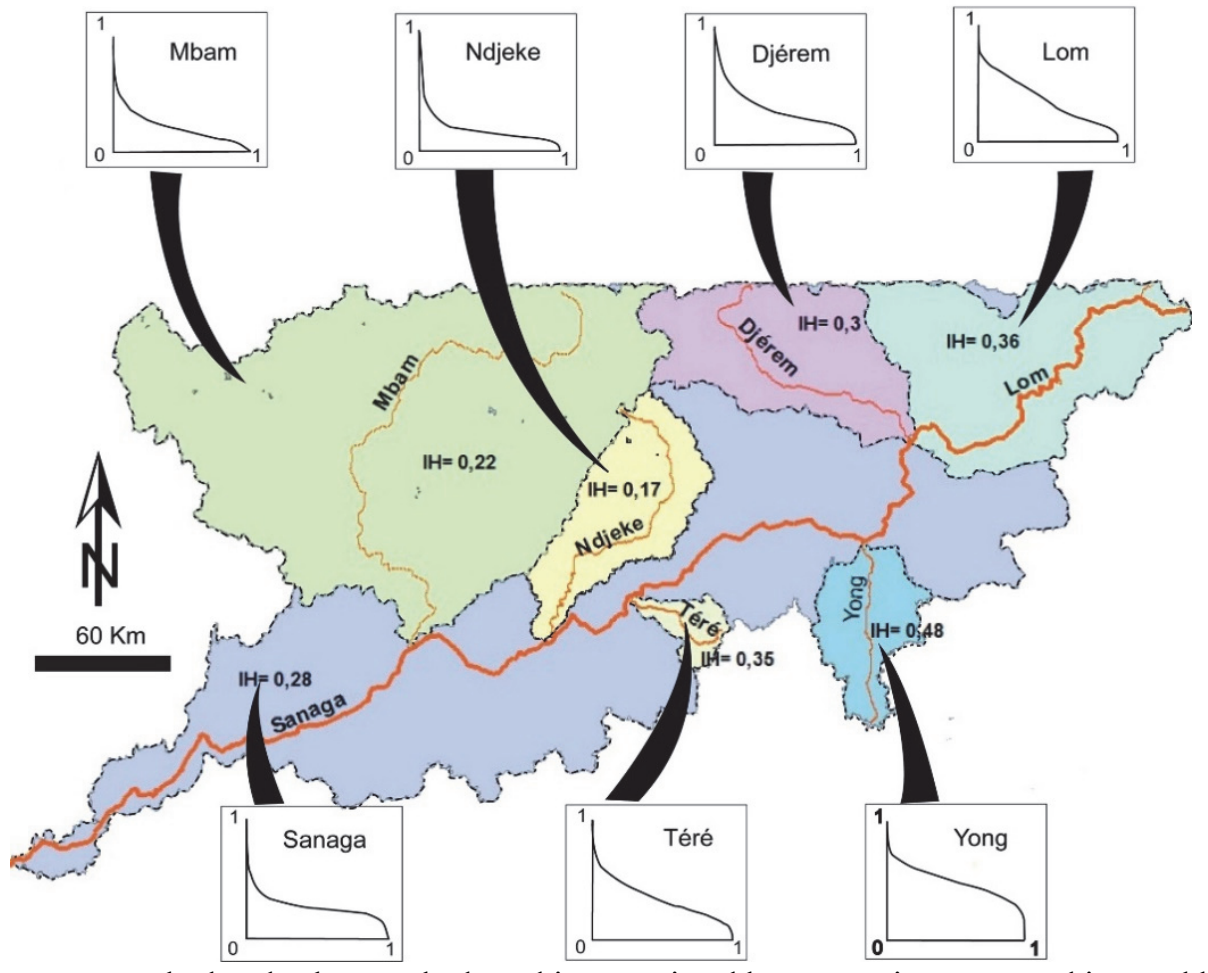

Figure 6. Sanaga watershed and subwatersheds and its associated hypsometric curves and integral hypsometry.

The hypsometric curves of these basins show complex shapes from concave to concavo-convex (Figure 6). The Ndjeke and the Mbam have essentially concave shapes whereas the other watersheds have concave or S-shapes rectified upstream and convex downstream. The HI values are low and variable ranging between 0.17 and 0.48 (Table 4). They can be divided into two groups: the first group has very low values $(\mathrm{HI}<0.3)$ and concerns the Ndjeke, Sanaga and Mbam watersheds while the second group has high values ( $\mathrm{HI} \geq 0.3)$ and concerns the Djérem, Téré, Lom and Yong. Given the ages of the different rivers, at least Pliocene, such values reflect the maturity of the basins but don't correspond to the morphology of their hypsometric curves which should have exclusively "S" and concave shapes respectively.

4.2.2 Drainage density (Dd), longitudinal profile (LP), concavity index (IC), deviation (D) and knickpoints (Kp)

Dd was calculated only for the Sanaga and the obtained value is 0.22 (Table 4). LP meanwhile have been realized for all trunk rivers. We used adimensional graphs in order to compare them (Figure 7a). Depending to the shape of the profile and the variation of the incision, three categories of profiles are observed: profile with double concavity for the Sanaga; diagonal or rectilinear profiles for the Djérem, Lom, Mbam, Téré and concave profile represented by the Ndjeke.

Correlations were established between river length and average gradient. For the same gradient, the profile shape can change. To compare the concavities of the profiles, we used concavity index (Langbein, 1964). The results show complex IC ranging between - 0.35 and 0.30 . The Sanaga and the Mbam present negative values whereas values for other rivers, although positive, are very low, less than or equal to 0.3 (Table 4).

The extent of incision and deviations of the different rivers are summarised in table 4 . D values vary from one river to another (Table 4, Figure 7b). The highest values are observed in the Sanaga (628 m) and the Ndjeke (325 $\mathrm{m})$, while the other rivers have low D values $(<150 \mathrm{~m})$. Other anomalies such as knicpoints have been determined on the Sanaga's long profile. The Sanaga longitudinal profile has recorded eight knickpoints, mostly coinciding with faults and more or less lithology (Table 5, Figure 8). 

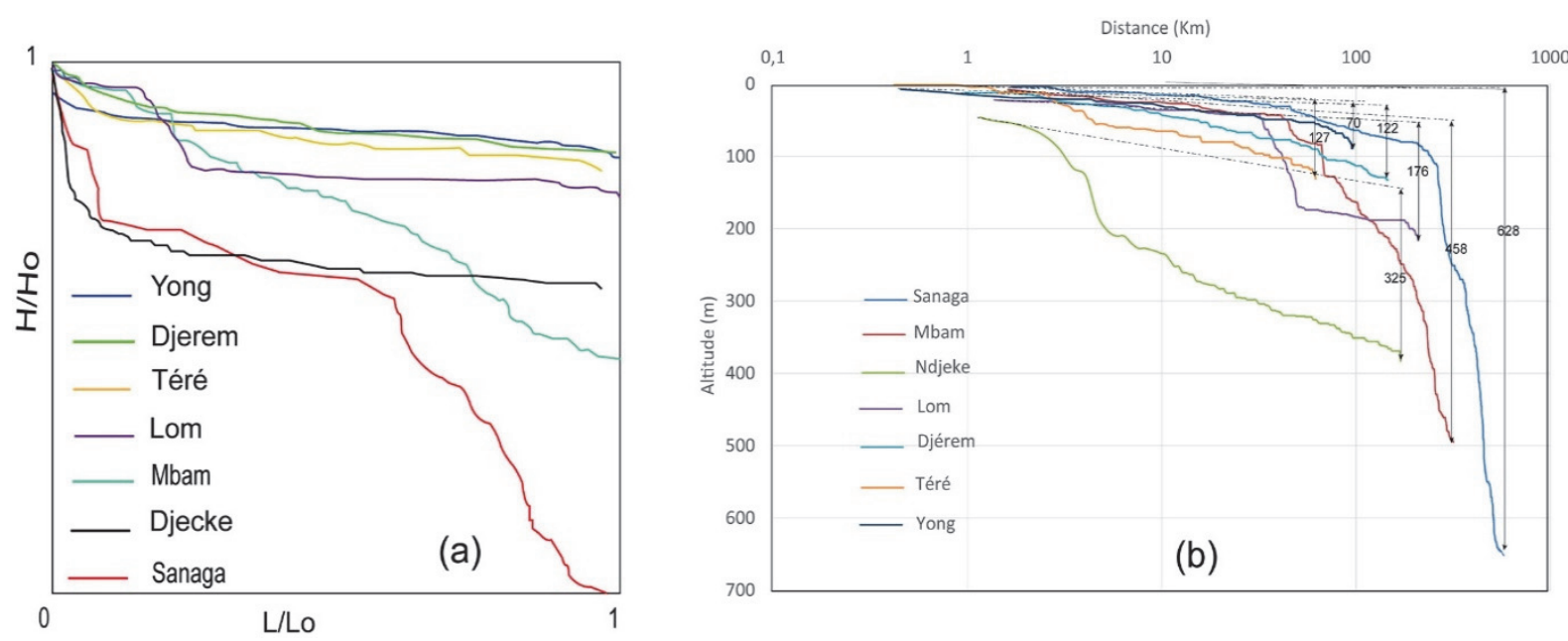

Figure 7. (a) Comparative longitudinal profiles through adimensional graphs: $\mathrm{H} / \mathrm{Ho}$ (ratio of elevations) and L/Lo (ratio of lengths). (b)- Longitudinal profiles of the rivers in semi-logarithmic coordinates, showing the deviations $\mathrm{D}$ in meters compared to the right of the equilibrium profile.

Table 5. Geometrical characteristics of Knickpoints (Kp) of the Sanaga River

\begin{tabular}{|c|c|c|c|c|c|c|c|c|c|}
\hline Kp & $\mathrm{H}(\mathrm{m})$ & $\mathrm{A}(\mathrm{m})$ & $\mathrm{DE}(\mathrm{km})$ & $\mathrm{DS}(\mathrm{km})$ & $\begin{array}{l}\text { Slope } \\
(\mathrm{m} / \mathrm{km})\end{array}$ & Lithology & & Confluences & Faults \\
\hline Kp1 & 15 & 104 & 81.01 & 5.5 & 2.73 & & & Tributary & NE-SW \\
\hline Kp2 & 2 & 102 & 69.01 & 17.5 & 0.17 & & & Tributary & NE-SW \\
\hline Kp3 & 18 & 84 & 54.71 & 31.8 & 1.26 & $\begin{array}{l}\text { Grt-Ky } \\
\text { gneiss/TTG }\end{array}$ & bearing & & NE-SW \\
\hline Kp4 & 2 & 82 & 49.01 & 37.5 & 0.35 & $\begin{array}{l}\text { Grt-Ky } \\
\text { gneiss/TTG }\end{array}$ & bearing & & W-E \\
\hline Kp5 & 6 & 76 & 45.31 & 41.2 & 1.62 & $\begin{array}{l}\text { Grt-Ky } \\
\text { gneiss/TTG }\end{array}$ & bearing & Pout Loloma & W-E \\
\hline Kp6 & 29 & 47 & 35.31 & 51.2 & 2.9 & & & & $\begin{array}{l}\text { WNW- } \\
\text { ESE }\end{array}$ \\
\hline Kp7 & 6 & 41 & 30.51 & 56 & 1.25 & & & Ngombè & NE-SW \\
\hline Kp8 & 19 & 22 & 28.51 & 58 & 9.5 & $\begin{array}{l}\text { Grt-Ky } \\
\text { gneiss/TTG }\end{array}$ & bearing & & NE-SW \\
\hline
\end{tabular}

H: Elevation of knicpoint; A : Altitude; DE : Distance to the outlet; DS: Distance to the source. 

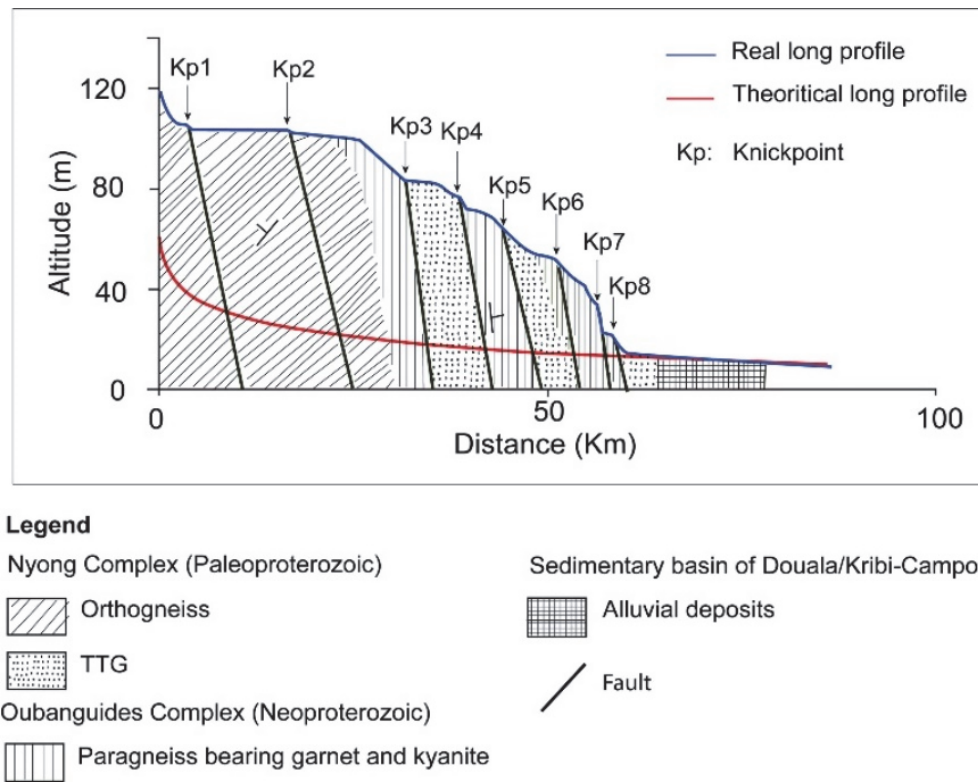

Sedimentary basin of Douala/Kribi-Campo

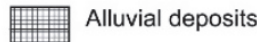

Figure 8. Longitudinal profile of the Sanaga river marked by geology

4.2.3 Valley floor width to valley height ratio (VF), Asymmetry factor (AF), Transverse topographic symmetry factor (TTSF) and Stream length-gradient index (SL) (Table 6)

These indices are specifically related to the tilting of a basin due to an uplift or the (re)play of a fault. VF is sensitive to tectonic uplift and neotectonic (Bull \& McFadden, 1977; Cuong \& Zuchiewicz, 2001). In Edéa region, VFindex varies from one subwatershed to another. The Djérem basin has an average VF of 20.06 and consists of Vshaped valleys that widen downstream, with high incision rate upstream and decreasing as we go downstream. With an average value of VF equal to 14.98 , the Lom basin consists of very wide V-shaped valleys with strong incision rate. The valleys are broad and V-shaped in the Mbam basin, with an average VF of 21.82 and a saw teeth incision. With an average VF of 24.83, the Ndjeke has broad valleys in V in its extremities and strong incision at the ends of the river. The Téré has an average VF of 12.92 with broad valleys in V very incised. This incision decreases downstream. The Yong has an average VF of 14 with narrow valleys upstream and broad downstream strongly incised. The Sanaga has V-shaped valleys, very wide with an average VF of 42.34 with a strong incision.

AF-index is also calculated for the 7 basins. The obtained values were divided into two classes: the first class consists of Lom, Ndjeke, Téré, Sanaga and Mbam basins which show low values of AF (less than 50) of rightward tilting and the second class with AF greater than 50, for the Yong and Djérem basins, implying their leftward tilting. As concerning TTSF, its values are low than 0.5, implying that the drainage is influenced by the tilting of the terrain due to tectonic activity. SL index was also been calculated for all the rivers. Its values are very significant only for the Sanaga (234.6) and the Mbam (256.28) rivers.

Table 6. Mean values of the morphometric indices of the studied Rivers.

\begin{tabular}{lclcl}
\hline \multicolumn{1}{r}{ Watersheds } & Mean TTSF & Mean Vf & AF & SL-index \\
\hline Ndjeke & 0.29 & 24.83 & 38.78 & 56.66 \\
Téré & 0.34 & 12.92 & 45.19 & 43.36 \\
Yong & - & 14.01 & 55.62 & 38.47 \\
Sanaga & 0.29 & 42.35 & 29.52 & 234.6 \\
Djerem & 0.21 & 20.06 & 53.21 & 39.04 \\
Mbam & 0.35 & 21.83 & 45.78 & 256.28 \\
Lom & 0.35 & 14.99 & 35.44 & 58.63 \\
\hline
\end{tabular}

\subsection{Structural Analysis}

The SW Cameroon was affected by a polyphased tectonic evolution quite visible in the Nyong and Oubanguide complexes. Field data recorded in the area are concentrated around Edéa where the formations are outcropping. 
Three phases of deformation were clearly observed: D1, D2 and D3. Figure 9 is a synthesis of some information collected from both the field, geological maps and DEM.

$\mathrm{D}_{1}$ is characterised by the $\mathrm{S}_{1}$ foliation mostly oriented N-S and E-W with dip bearing towards the West, East and North and isoclinal folding $\mathrm{P}_{1}$ plunging eastwards. $\mathrm{P}_{1}$ folds show axes with bearing of N04 ${ }^{\circ} \mathrm{E}$, with a slight south plunge. The hinges of these folds indicate that they are affected by the $\mathrm{D}_{2}$ deformation phase.

$D_{2}$ is materialized by $P_{2}$ folds reflecting N-S shortening, $A_{2}$ fold axes plunging towards the West, $S_{2}$ schistosity oriented N-S, parallel to $S_{1}$, and constituting with it a composite surface $S_{1} / 2 ; L_{2}$ lineation printed by stretching mineral and crenulation with a N-S direction and a North direction of plunging, striae grooves either N-S and northern plunge at Sanaga-Carrière, ALUCAM and Pout Loloma, or E-W direction with a West plunge at Mbanda. These structures overlap the Congo craton towards the South. $\mathrm{D}_{1}$ and $\mathrm{D}_{2}$ phases occurred during Eburnean/TransAmazonian orogenies and remobilized during the Pan-African, are the expression of an equilibrium between the brittle and ductile contexts.

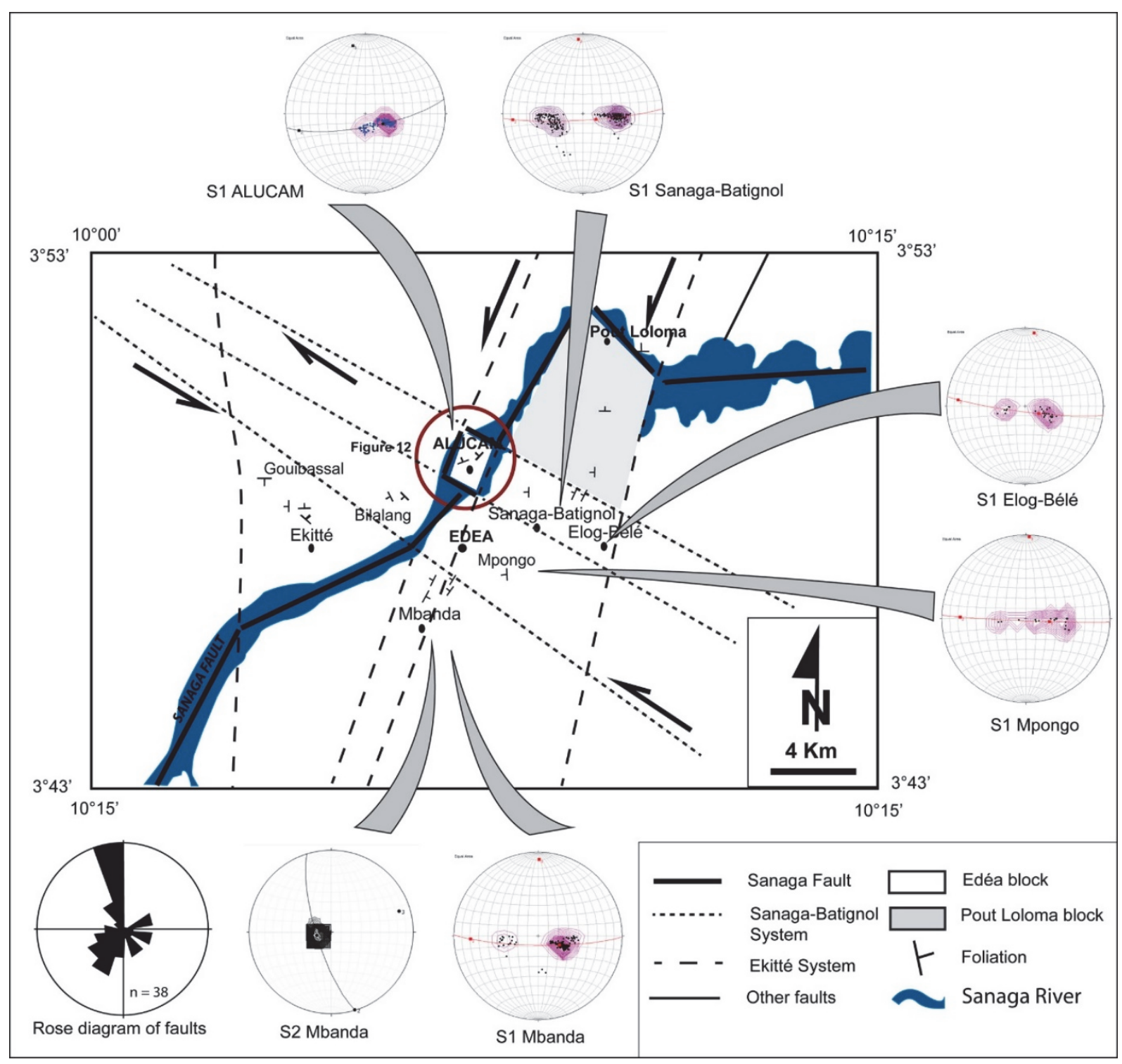

Figure 9. Tectonic map of study area showing the Ekitté and Sanaga-Batignol Faults Systems obtained from DEM and field data and spatial distribution of density diagrams and combined poles of $\mathrm{S}_{1}$ foliation inside the different blocks.

The third deformation phase regroups joints and late stage metamorphic faults. These faults were observed both 
on DEM and on outcrops. Figure 9, enables us to distinguish two major systems of subperpendicular faults all attached to the SF. a N-S to NNE-SSE system named Ekitté System (ESF), constituted by normal and strike-slip faults responsible for the reverse $\mathrm{S}_{1}$ foliation observed at Mbanda and Ekitté localities and the NW-SE system, named Sanaga-Batignol System (SBSF), constituted by normal faults and strike slips well observed at Issongé and Sanaga-Batignol localities respectively (Figure 10). The N-S strike-slip mirror with easthern front at Pout Loloma is one of the most evident of the Ekitté system on the field (Figures 10c \& d). These mirrors are not in the same level, but wavy. The direction of movement is parallel to the direction of subhorizontal grooves which indicate horizontal displacement. In conclusion, $\mathrm{D}_{3}$ phase, exclusively brittle is post-orogenic (post Pan African). It is due the replay of the ancient faults among which the Sanaga Fault, thereby creating a network of secondary faults, hence the two systems of the Sanaga. This phase, since its current, it contributes deeply to the neotectonic phase.

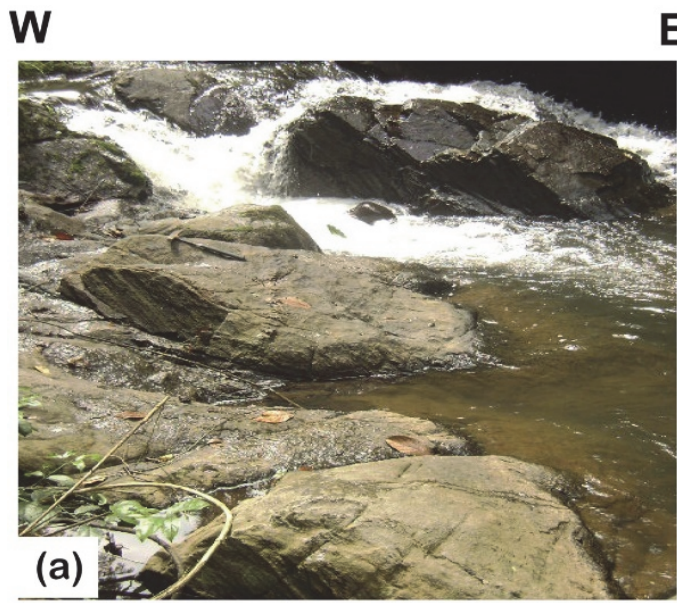

E $\mathbf{N}$

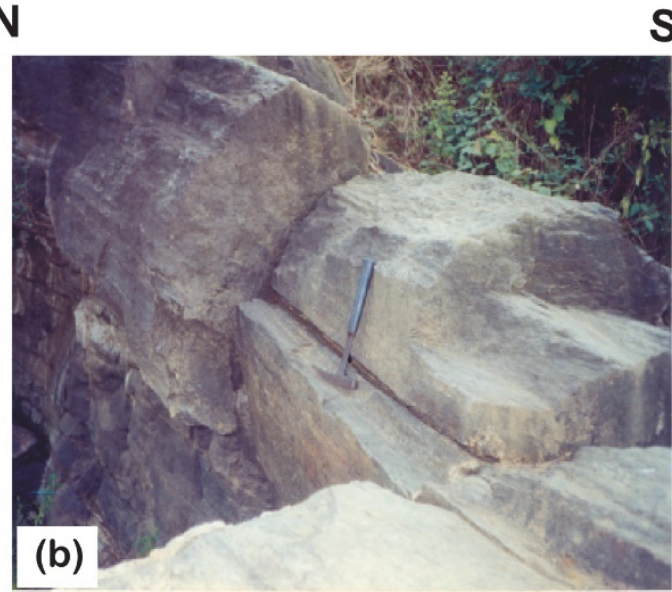

N

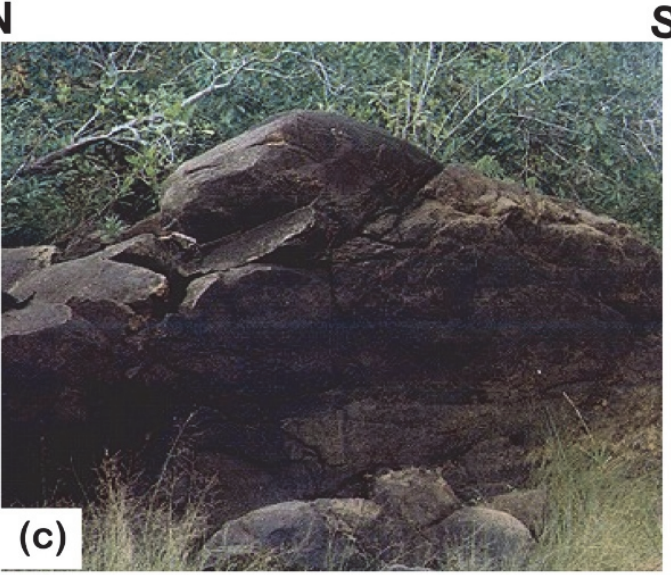

N

S

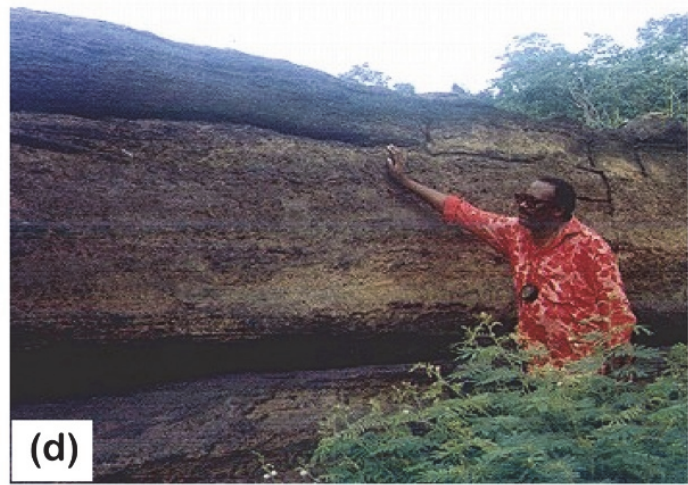

Figure 10. Main tectonic features observed in the study area. (a) and (b)- NW-SE Sanaga-Batignol System Fault constituted by strike slips at Sanaga-Batignol and normal faults at Issongé; (c) and (d)- N-S strike-slip mirrors belonging to Ekitté system observed at Pout Loloma

\subsection{Petrographic Analysis}

Except, the Pan African Formations which overlap the Eburnean Formations well described (Lasserre \& Soba, 1979, Penaye et al., 1993; Toteu et al., 1994), two new petrographic types never described are observed in the study area: the pseudotachytes and tectonic breccia. These tectonogenic rocks result from the transformation of the biotite and amphibole gneiss. This transformation is quite evident on the Pout Loloma outcrop (Figure 11g) through a slip surface showing parallel crenulation $\left(\mathrm{N} 05^{\circ} \mathrm{E} 12^{\circ} \mathrm{N}\right)$, striation $\left(\mathrm{N} 06^{\circ} \mathrm{E} 25^{\circ} \mathrm{N}\right)$ and lineation's carried by $S_{1}$. This surface serves as a sole on which slip occurs. The pot hole filled by rounded quartz pebbles and gneiss clasts of different natures welded by black amorphous groundmass. Note the presence of a halo around the pot, a proof that the material inside was very hot during its deposit. 
The pseudotachylites, parallel to the foliation at the level of gneiss are rust-coloured rocks and located at the level of the foliation of the biotite and amphibole gneisses. They are constituted by an amorphous paste derived from intense friction due to relative block dislocation. Their thickness varies from millimeter to centimeter. They are characterized by dark matrix with inclusions of fine minerals or rock fragments where they outcrop. They are glossy verging volcanic glass. Their amygdal structure refers to the presence of gas bubbles within the matrix.

The tectonic breccias on the other hand include two main types: monogenic breccia essentially constituted by quartz (Figures 10a \& b) and polygenic breccias (Figure 10c) constituted by quartz pebbles with various shapes (sub-rounded to rounded) and gneissic clasts interbedded by cement derived from the intense melting (Figure 10d $\&$ e) by brittle shearing of the parent rock (biotite and amphibole gneiss). The quartz remains of the latter are completely laminated. According to Dufaure (2005), these types of rocks are frequent along unearthed fault plains, precisely, at Pout Loloma, the mirror is a slickenside with laminated quartz (Figure 10f). 

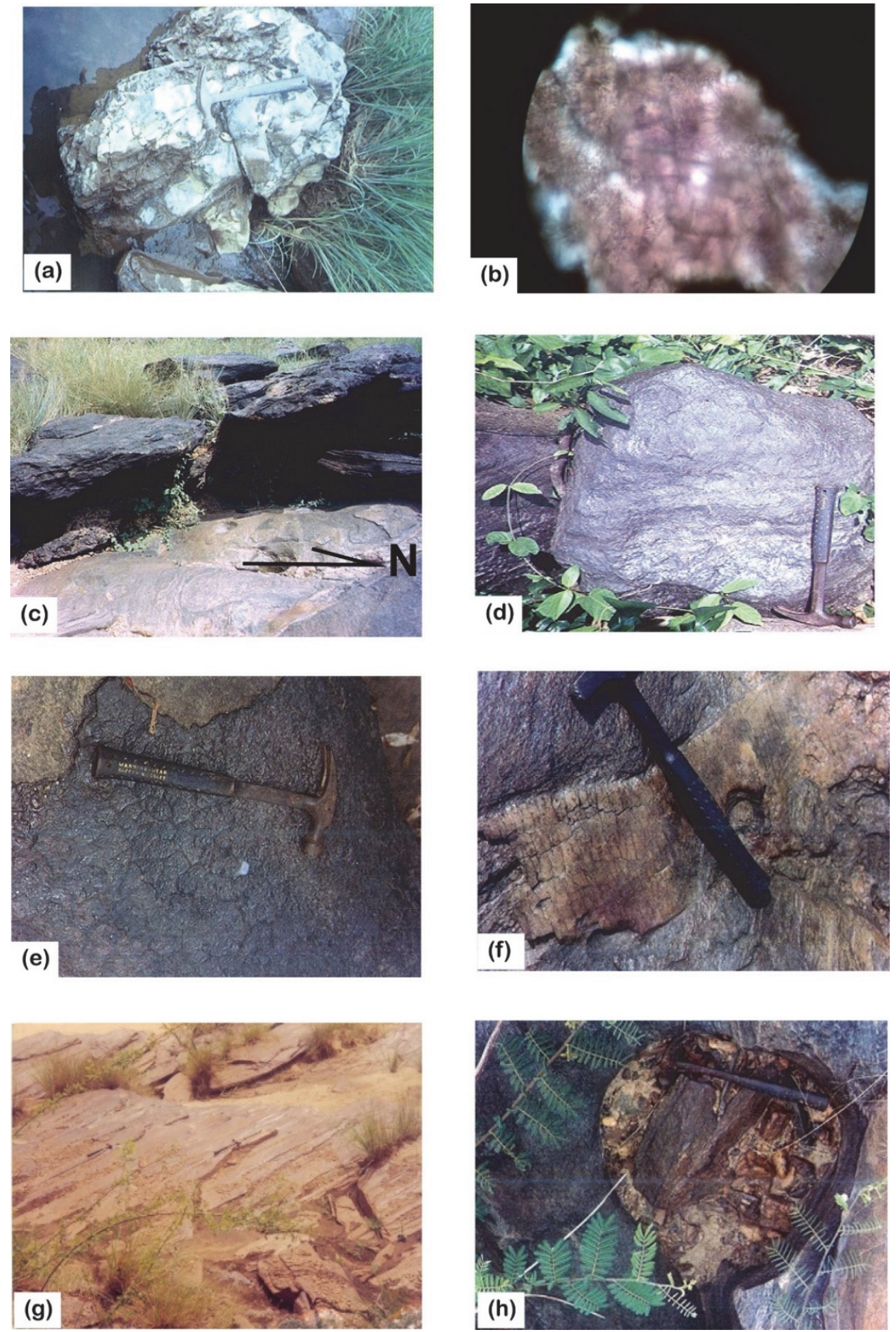

Figure 11. Main petrographic features observed at Pout Loloma

(a) and (b). monogenic tectonic breccias respectively at the field and on microscope with quartz grains completely crushed; (c). polygenic tectonic breccias; (d). gneiss completely crushed observed at Pout Loloma locality, with all parent rock structures erased by intense rubdown due to a differential slip; (e). mmorphous groundmass containing small quartz grains, resulting of the intense rubdown of gneiss on foliation plane $\mathrm{S} 1$; (f). crushed quartz on foliation plane S1; (g). slip surface showing parallel crenulation $\left(\mathrm{N} 05^{\circ} \mathrm{E} 12^{\circ} \mathrm{N}\right)$, striation $\left(\mathrm{N} 06^{\circ} \mathrm{E} 25^{\circ} \mathrm{N}\right)$ and lineation's wore by S1 at Pout Loloma locality; (h). pot hole filled by rounded quartz pebbles and gneiss clasts welded by black amorphous groundmass. Note the presence of a halo around the pot, a proof that the material inside was very hot during its deposit. 


\section{Discussions}

The purpose of this study was to highlight the impact of the SF activity on the Edéa landscape and its implication for the Neotectonics. In this section, we discuss the consequences of its reactivations on the drainage system, the landscape evolution and the relationship with seismicity.

\subsection{Network Patterns}

The Edéa drainage system displays predominantly dendritic pattern in conformity with the crystallophyllian nature and the impermeable character of the basement made of Nyong and Oubanguide complexes and dissymmetric pattern (Mevia and Ossa lakes) developed on the more permeable sedimentary cover. Otherwise, the angular and parallel tendencies of drainage patterns of the Sanaga river as well as the Ossa lake and the N-S lengthened of Mevia lake, located on the Mevia fault (Nsangou et al. 2017) attest that these river and lakes are under tectonic control. Secondly, the comparison between the main flow directions of streams order $\geq 4$ (Figure 4) and the main directions of the Pan African fractures (see rose diagram of faults on figure 9; Njiké Ngaha, 1984; Kossoni, 1992) and those linked to the opening of the South Atlantic during the Apto-Albian (Benkhelil, 2002), show direct correspondence and lead to the conclusion that the SF and its systems constitute the river beds.

\subsection{Geomorphic Anomalies}

Geomorphic indices reveal numerous morphological anomalies related to tectonics (Table 4). Concerning the hypsometric curves, except Ndjeke and Mbam basins which present concave shapes, the other basins display complex shapes including S-shapes rectified upstream and convex downstream (Figure 6). Such shapes reflect an uplift near a major fault or an uplift associated with recent collapse (El Hamdoui et al., 2007). In our case, the most important fault known is the SF. HI is used to discriminate tectonically active zone to inactive zone (Keller \& Pinter, 1996). In the study area, $\mathrm{HI}<0.5$, given the ages of the different rivers, at least Pliocene, this imply the maturity of the basins but do not correspond to their hypsometric curves which should be in "S" or concave (Strahler, 1952; Ohmori, 1993 and Delcaillau et al., 1998). This confirms the uplift of the region and is reinforced by the low value of the drainage density of the Sanaga basin $(0.22<1)$ which is a characteristic of recent tectonics (Melosh \& Keller, 2013). Snyder et al. (2000), Kirby and Whipple (2001) and Roe et al. (2002), have demonstrated that when the IC value is ranging between - 0.35 and 0.30 , the region has undergone an active uplift and when its value is comprised between 0.30 and 0.60 , the region is assumed to be stable. The first case corresponds to what is observed in the study area. Within the same line of thinking, LPs are very sensitive linear aspect for every drainage basin with tectonic deformation (Lahiri \& Sinha, 2012; Viveen et al., 2012; Fekete \& Vojtko, 2013; Goren et al., 2014). The effects of tectonics are conveyed in terms of deviation (D) and knickpoints (Kp). D values are more than $250 \mathrm{~m}$ for the Sanaga, Mbam and Ndjeké and less than $150 \mathrm{~m}$ for the other rivers. The high values of D are often due to the presence of faults or lithological contrasts. In the case of this work, they are more related to faults, the lithology little varying. Therefore, these basins have undergone a more recent uplift compared to the other basins whose long profiles are close to equilibrium. Eight Kps have been recorded by the Sanaga river profile. The geologic section shows that these Kps are due to faults even though some coincide with lithological contrasts (Figure 8, Table 5). That reiterates the structural control of the drainage system.

The tilting of the drainage basins as well as the magnitude of the incision due to uplift or replay of the SF, have been evaluated with VF, TTSF and AF (Table 4), which are very sensitive to uplift and neotectonics (Bull \& McFadden, 1977; Cuong \& Zuchiewicz, 2001). The results show that most of the basins have V-shaped valleys with strong incisions, particularly for the Sanaga. Theoretically U-shaped valleys are indicative of the less tectonic activity and V-shaped valleys, as a response to uplift, are associated with high tectonic activity (Bull and McFadden 1977; Burbank and Anderson 2001; Keller and Pinter 2002). TTSF meanwhile indicates the deviation of trunk river from the mid-line of the basin or lateral tilting (Ribolini, 2000). In all the basins, the values of TTSF are lower than 0.5 , showing that the drainage is influenced by the tilting of the terrain due to tectonic activity. As TTSF, $\mathrm{AF}$ was used to understand if and how drainage has been developed under tectonic control in a quantitative manner (Guarnieri and Pirrotta, 2008; Sarma et al., 2013; Kale et al., 2014). It appears that Ndjeke, Téré, Sanaga, Mbam and Lom sub-basins with $\mathrm{AF}<50$ are rightward tilted while Yong and Djérem with $\mathrm{AF}>50$ are tilted to the left. SL index is present where rivers are crossing the hard rocks or reflects relatively high tectonic activity (Hack, 1973; Keller and Pinter, 2002). In the study area, the highest values were observed in the Sanaga and Mbam basins implying high tectonic activity of the SF.

In conclusion, it appears clearly that, the study have undergone and is currently undergoing uplifts, tilting due to the reactivations of the SF. Such replays have favored the structuring of the region into tectonic blocks and are well expressed through the recent earthquakes that occurred since the beginning of this century in Edéa-Kribi region (Ateba Bekoa et al., 1992; Ntepe et al., 2004; IRGM, 2006). 


\subsection{Block Tectonics}

We showed above that, the SF includes two systems of faults: the N-S ESF and the NW-SE SBSF (Figure 9). The absolute ages of these faults are not available. The SF has been assigned by Dumont (1986) to be Proterozoic, then the two systems that constitute it are undoubtedly posteriors since they cross it. Following the parallelism between the direction of the ESF and that of the Cretaceous rifting that led to breakup of the Gondwana, we propose that the ESF was set up during this period. Furthermore, on the field, the ESF cut all the other structures such as the $\mathrm{S}_{1}$ foliation, $\mathrm{P}_{2}$ folds which are Pan African, confirming that these faults may be at least Albo-Aptian age. The SBSF would be the same age or so younger.

The two systems of faults are diachronous and structure the region into block tectonics or parquets, a parquet being a lithological band limited by two nearby parallel faults of a system which undergo a differential slip along the faults at the favour of schistosity. The replays of the two systems are responsible for the displacement of the blocks. The study area displays several parquets, but the Pout Loloma and the ALUCAM blocks are the well expressed (Figure 9). The Pout Loloma block, more than $6 \mathrm{~km}$ wide and $6 \mathrm{~km}$ length is submitted to a sub-meridian polarity slip. On the outcrops, the presence of quartz laminations, parallel crenulation, striation, $\mathrm{L}_{2}$ lineation plunging towards the North (Figure 11g) and especially that of the crushed breccia and pseudotachylites (Figures 11a, e, f) are clear evidence of the dislocation and intense friction that have undergone the gneisses during this slip. The ALUCAM Block, about $2 \mathrm{Km}$ wide and $2 \mathrm{~km}$ length has undergone slip towards the West (Figure 12b), and simultaneously edifying N-S trending V-shaped valleys at a few meters away from the ALUCAM and parallel to the dead arm of the Sanaga River. The age of the establishment of these blocks is difficult to determine in absence of constraints on the age of the faults that control them. Considering the Sanaga river as a reference point, and considering that the characteristics of the drainage pattern of South Cameroon result to the uplift of the Adamawa plateau during the reactivation of the CCSZ during the Paleocene (Yéné Atangana \& Poudjom Djomani, 2001), we suggest that the dislocation of these blocks is extremely young at least Paleocene.

Through the figure 12, we try to reconstitute the SF action on the Edéa landscape. Indeed, the SF set up during the Proterozoic (Figure 12a), has first played in transtension during the breakup of Gondwana (upper Cretaceous) which favored the development of the ESF and the installation of the river (Figure 12b). During the uplift of the Adamawa plateau (Paleocene), the SBSF is set up leading to the formation of the ALUCAM block (Figure 12c) and plays as dextral slip faults causing the deviation and the displacement westward of the Sanaga river and the ALUCAM block (Figure 12d). Later, the reestablishment from South to North of the flow direction of the river is observed at Sanaga-Batignol (Figure 12e). Through capturing, the stream found back the N-S flow, thereby isolating the Sanaga dead arm, 1.5 Km long (Moussango Ibohn, 2003). We attach this period to a replay of the NS system which may have occurred when the Mount Cameroon became active during the Pliocene (Déruelle et al. 2007). This evolution justifies the presence of two bridges spaced about $1.5 \mathrm{~km}$ in the Edéa city. From this time, the SF and its systems play iteratively. The several earthquakes occurred in the region, most of them related to the SF, the Sanaga dead arm, the criss-crossing area, the braided network and the occurrence of block tectonics may all be the consequences of these reactivations. 


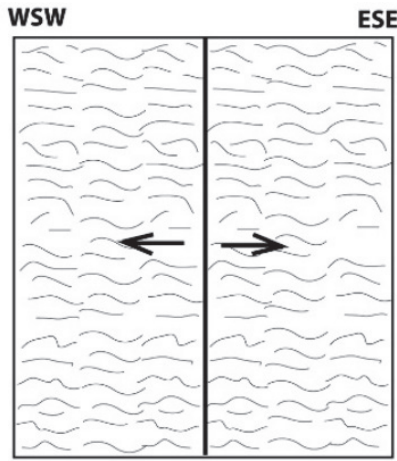

(a)

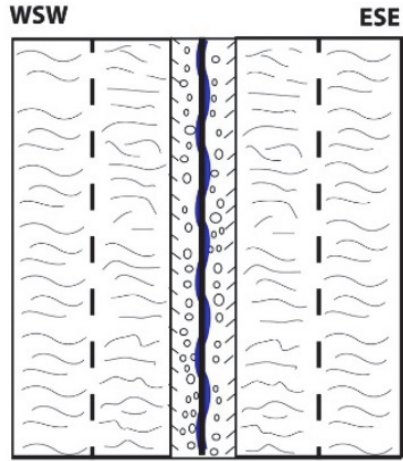

(b)

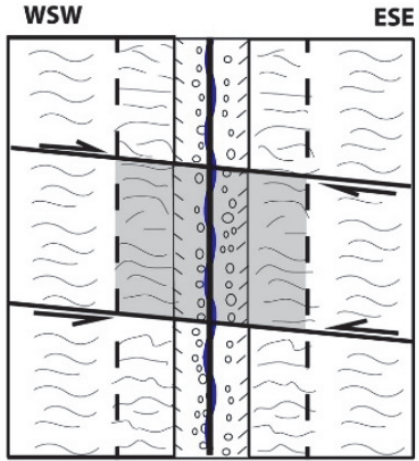

(c)

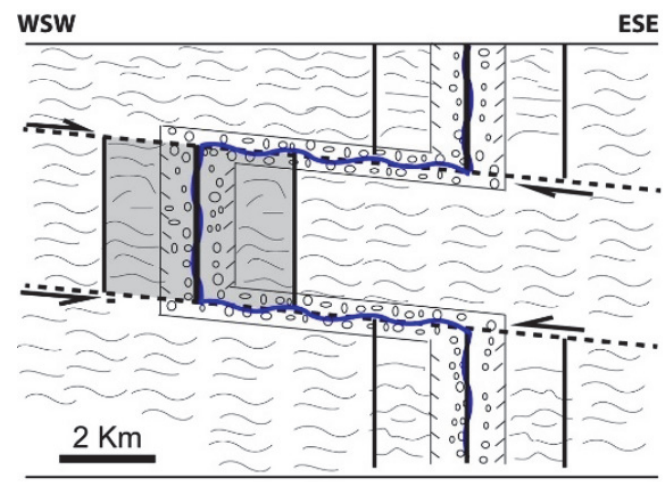

(d)

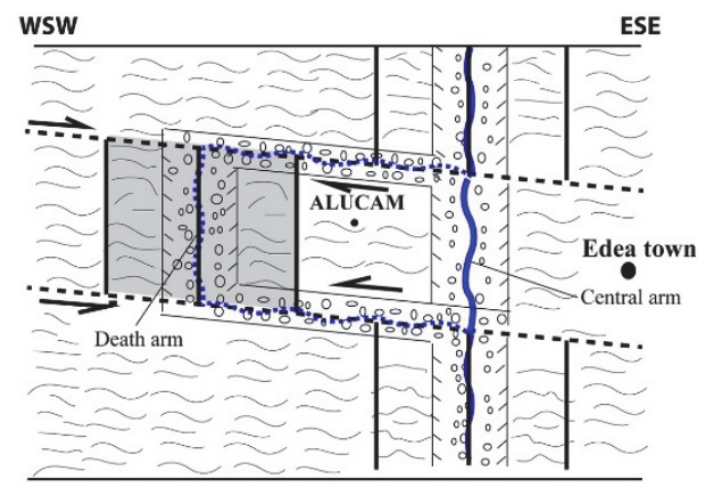

(e)

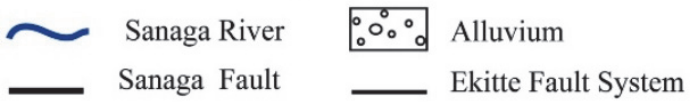

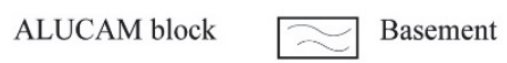

Sanaga-Batignol Fault System

Figure 12. Model of development of the Edéa landscape in Edea town and formation of blocks tectonics

(a): establishment of the SF (Proterozoic); (b): establishment of the Ekitté system and installation of the the Sanaga River (Cretaceous); (c)- establishment of the Sanaga-Batignol System (Plaleocene); (d)- strike slip play of the SBSF leading to the deviation of the water course and the formation of ALUCAM block; (e) restoration of the direction of the watercourse and isolation of the dead arm of the Sanaga (Pliocene).

\subsection{Seismic Activity}

An active fault is a fault that is likely to become the source of another earthquake sometime in the future. Geologist commonly consider fault to be active if there has been movement observed or evidence of seismic activity during the last 10,000 years. Data from Ateba Bekoa et al. (1992) and IRGM (2006), show that the SF is an active one, the recent example, being the earthquake of $19^{\text {th }}$ march 2005 of 4.4 magnitude on the Richter scale, attributed to the reactivation of this fault. Shandini Njankouo (2005) has also shown that the junction between the geophysical limit of the Congo craton and the SF (Figure 13) and with Kribi Fault constitute also potential seat points of seismic activity. It is thus probable that the NNE-SSW Kribi Fault encountered at the Atlantic Ocean is the prolongation in the sea of the geophysical limit of the Congo craton (Atéba Bekoa et al., 1992; Koumetio, 2004) and could belong to the Ekitté System. Previous seismic surveys (Atéba Bekoa et al., 1992; Ntepe Nfoumou et al., 2004; IRGM, 2006) confirm that the SF was characterised by a long period of quiescence interrupted by brief episodes of seismic activity. Consequently, it can be qualified as slow fault contrary to fast faults which give rise to destructive seismic waves with intermediate recurrences (Bertrand et al., 2007). The neotectonics can then be highlighted by the current seismic activities. About 33 earthquakes have been felt since 1900. Eleven of the felt earthquakes occurred in southern Cameroon, especially the Edéa-Kribi area with magnitudes varying between 2.6 and 4 on the Richter scale (Table 7). The most significant is the September 1945 shock which had its highest intensity along the Sanaga river causing the collapse of riverbanks, and constitute the strongest earthquake yet recorded in the region and in Cameroon. It was perceptible for over $420 \mathrm{~km}$ from the instrumental epicentre and also affected parts of Congo and Central African Republic (Ambraseys and Adams, 1986). 
Table 7. Earthquakes affected Kribi and Sanaga faults. It is an update of previous compilations by Ambraseys and Adams (1986), Ateba Bekoa et al. (1992) and Tabot et al. (1992)

\begin{tabular}{llll}
\hline Date & Epicentre & Coordonnées géographiques & Magnitude \\
\hline $18 / 08 / 1987$ & Edéa-Kribi & & 4.0 \\
$04 / 09 / 1987$ & Edéa-Kribi & $3,2^{\circ} \mathrm{N}$ et $9,9^{\circ} \mathrm{E}$ & 2.6 \\
$10 / 09 / 1987$ & Edéa-Kribi & & 4.0 \\
$11 / 09 / 1987$ & Edéa-Kribi & $3,2^{\circ} \mathrm{N}$ et $10,1^{\circ} \mathrm{E}$ & 3,7 \\
$17 / 09 / 1987$ & Edéa-Kribi & $3^{\circ} \mathrm{N}$ et $10^{\circ} \mathrm{E}$ & 3.3 \\
$18 / 08 / 1987$ & Edéa-Kribi & $3,8^{\circ} \mathrm{N}$ et $10,4^{\circ} \mathrm{E}$ & 2.8 \\
$19 / 03 / 1988$ & Edéa-Kribi & $3,5^{\circ} \mathrm{N}$ et $9,9^{\circ} \mathrm{E}$ & 3.4 \\
$14 / 03 / 1989$ & Edéa-Kribi & $4^{\circ} \mathrm{N}$ et $11,4^{\circ} \mathrm{E}$ & 2.8 \\
$16 / 03 / 1989$ & Edéa-Kribi & $3^{\circ} \mathrm{N}$ et $9,7^{\circ} \mathrm{E}$ & 3.5 \\
$13 / 07 / 1989$ & Edéa-Kribi & & 3.5 \\
$23 / 07 / 2002$ & Kribi & $3^{\circ} \mathrm{N}$ et $9^{\circ} \mathrm{E}$ & 3.2 \\
$19 / 03 / 2005$ & Edéa-Kribi & & 4.0 \\
\hline
\end{tabular}

Otherwise, the presence of pseudotachylites, parallel to the foliation at the level of gneiss implies that they are of generation type (Sibson, 1975; Swanson, 1988) and due to an active fault (Obata \& Karato, 1995 et Ueda et al., 2008). These rocks are always set up by brittle shear deformation during earth tremors. Bossiere (1991), has demonstrated that they are genetically related to the earthquake phenomena. The crushed breccias observed on the outcrops, on the fault plans and on the $\mathrm{S}_{1}$ foliation surfaces play a role of rubified plastic quartz. Similarly, those that are constituted of rounded quartz of variable sizes and welded by cement support this idea and reveal that the sedimentary load of the Sanaga is implicated in the dislocation of Pout Loloma Block. The pot holes with aureoles (Figure 11h) filled by polygenic crush breccia confirm the displacement of this block. Indeed, amorphous paste, result of the biotite and amphibole gneiss melting during the dislocation of the parquet, seals quartz pebbles and the fragments of the melted rock within the giant pot hole under the effect of wetting. Therefore, these rocks are good indicators of neotectonics and seismic activity. In conclusion, the SF and the northern limit of the Congo craton may have been frequently reactivated as seen from the concentration along them of most of the historic and recent tectonic seismicity in Cameroon (Ntepe Nfoumou et al. 2004).

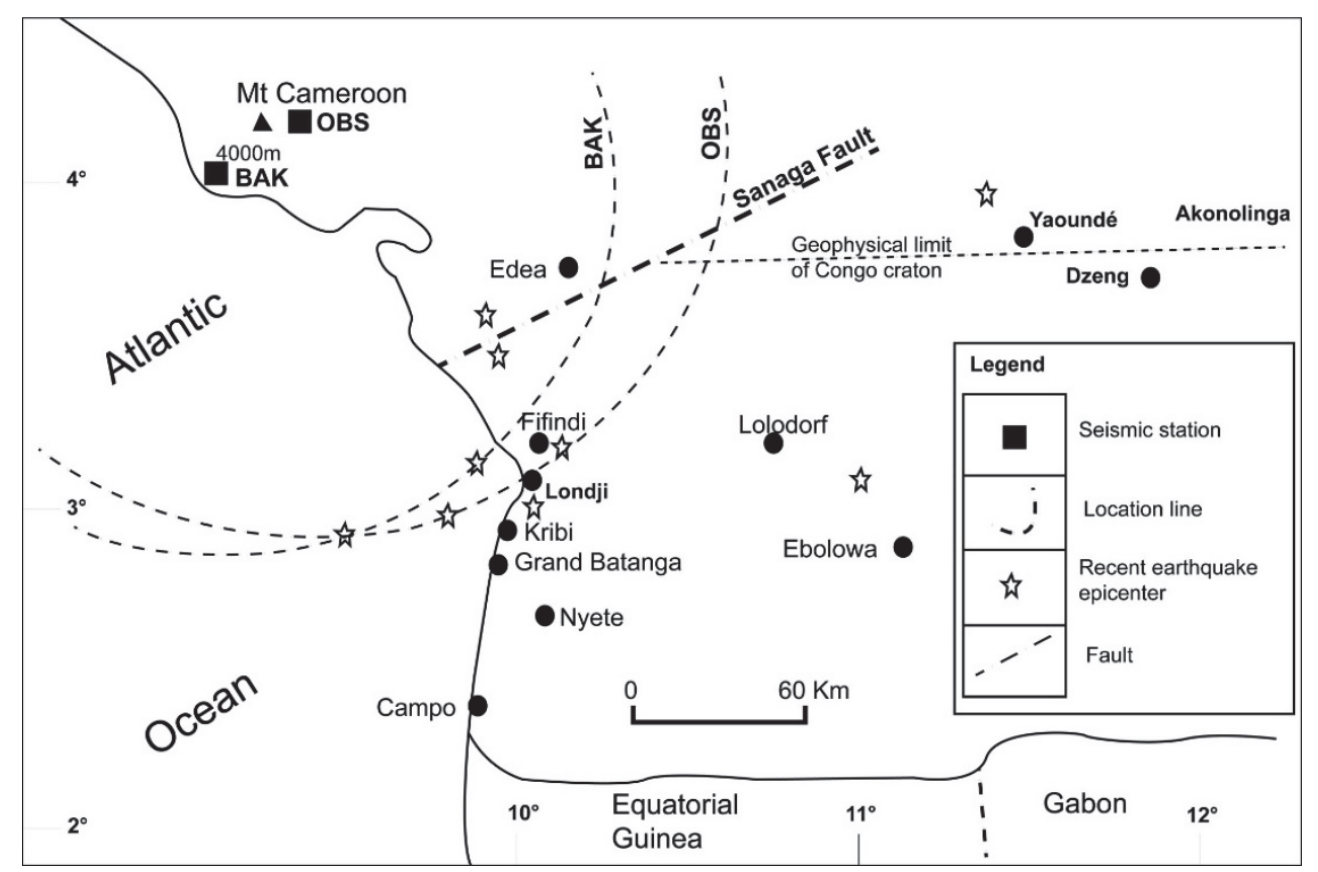

Figure 13. Location of the recent earthquakes as recorded by two stations (BAK and OBS) of the mount Cameroon seismic monitoring nerwork (Ntepe et al., 2004).

\section{Conclusion}


The purpose of this study was to highlight the impact of the tectonic activity of the SF on the Edéa landscape and its contribution to the Neotectonics. Focused on numerical and graphical indices extracted from DEM $(90 \mathrm{~m})$, field data obtained from field campaigns and previously established works, the study reveals that the SF is a very active tectonic feature that crosses the margin and affects deeply the Edéa region.

This fault includes two systems of secondary active faults: the SBSF which is a set of NW-SE trending faults cut by the ESF faults oriented N-S to NNE-SSW. The two systems have segmented the region into block tectonics. The absolute ages of these faults or of the occurrence of tectonic blocks are not available. The conceptual model constructed highlights the various stages of geomorphic development with respect to the SF activity. Set up during the Proterozoic, the SF has first played in transtension during the upper Cretaceous and favored the installation of the river and the development of the ESF. During the Paleocene, the Adamawa plateau is uplifted and favored the establishment of the SBSF and then the block tectonics. The strike-slip or brittle shear displacement of these blocks are responsible for the pseudotachylites, tectonic breccia and slow earth tremors.

Morphometric parameters used are consistent to this evolution and further show that the study area have experienced and continuous to experience uplifts and tilting orchestrated by the reactivations of these faults. Such reactivations are responsible for the current landscape configurations and the actual drainage patterns. The recent earthquakes, recorded since the beginning of this century in Edéa-Kribi region, with certain generated by the SF are both the consequence of these reactivations and the best illustrations of the neotectonics in the region.

\section{Acknowledgements}

Thanks to Azinwi P. Tamfuh and Serge Goran who translate this work. The authors also thank the anonymous reviewers for their insightful, pertinent and useful comments. Special thanks go to Assistant Editor Lesly Lu for its constructive suggestions to make the paper better.

\section{References}

Ambili, A. C., \& Narayana, V. (2014). Tectonic effects on the longitudinal profiles of the Chaliyar River and its tributaries, southwest India. Geomorphology, 217, 37-47.

Ambraseys, N. N., \& Adams, R. D. (1986). Seismicity of West Africa. Ann.Geophys, 4, 679-702.

Atéba, B., Ntepe, N., Ekodeck, G. E., Soba, D., \& Fairhead, J. D. (992). The recent earthquakes of Cameroon and their possible relationship with main geological features of Central Africa. J. Afr. Earth Sciences, 4(3), 365369.

Benkhelil, J., Giresse, P., Poumot, C., \& Ngueutchoua, G. (2002). Lithostratigraphic, geophysical, and morphotectonic studies of the South Cameroun shelf. Marine and Petroleum Geology, 19, 499-517. https://doi.org/10.1016/S0264-8172(02)000028

Bertrand, G., Bellier, O., Bollinger, L., Cushing, M., Durouchoux, C., Hollender, F., Meyer, B., Sabourault, P., Schlupp, A., Sébrier, M., \& Herniot, P. (2007). NéoPal: Base de données nationale des déformations néotectoniques et des paléoséismes. 7ème Colloque National AFPS 2007-Ecole Centrale Paris 3.

Bossière, G. (1991). Pétrology of pseudotachylytes from the Alpine Fault of New, Zealand, Tectonophysics, ${ }^{\circ}$ 196, Elsevier Science Publishers B. V., Amsterdam, pp. 173-193.

Bull, W. B., \& McFadden, L. D. (1977). Tectonic Geomorphology North and South of the Garlock Fault, California. In: Doehring, D. O., Ed., Geomorphology in Arid Regions: A Proceedings Volume of the 8th Annual Geomorphology September 1977, 115-138.

Burbank, D. W., \& Anderson, R. S. (2001). Tectonic Geomorphology. Blackwell Scientific, Oxford. 270 pp.

Chen, V. E., Quocheng, S., \& Cheng, K. Y. (2003). Along-strike variations of morphometric features in the Western foothills of Taiwan: Tectonic implication based on stream-gradient and hypsometric analysis. Geomorphology, $56,109-137$.

Cornacchia, M. (1980). Les failles du Nord de la République Centrafricaine (conséquenses tectoniques). Bull. Ann. CNRS, 5, 76-80.

Cornacchia, M., \& Dars, R. (1983). Un trait structural majeur du continent africain. Les linéaments centrafricains du Cameroun au Golfe d'Aden. Bull. Soc.Géol., Fr., 7, t. XXV, n¹.

Cox, R. T. (1994). Analysis of Drainage Basin Symmetry as a Rapid Technique to Identify Areas of Possible Quaternary Tilt Block Tectonics: An Example from the Mississippi Embayment. Geological Society American Bulletin, 106, 571-581. https://doi.org/10.1130/0016-7606(1994)106<0571:AODBSA>2.3.CO;2 
Cuong, N. Q., \& Zuchiewicz (2001). Morphotectonic properties of the Lo River Fault near Tam Dao in north Vietnam, Natural Hazards and Erath System Sciences, 1, 15-22.

Dar, R. A., Romshoo, S. A., Chandra, R., \& Ahmad, I. (2014). Tectono-geomorphic study of the Karewa Basin of Kashmir Valley. Journal of Asian Earth Sciences, 92, 143-156.

De Almeida, F. F. M., Hasui, Y., Neves, B. B., \& Frank, R. (1981). Brasiliano structural provinces: An introduction. Earth Sci. Rev., 17, 1-29.

Delcaillau, B., Deffontaines, B., Floissac, L., Angelier, J., Deramond, J., Souquet, P., Chu, H. T., \& Lee, J. (1998). Morphotectonic evidence from lateral propagation of an active frontal fold; Pakuashan anticline, foothills of Taiwan. Geomorphology, 24, 263-290.

Demoulin, A. (1998). Testing the tectonic significance of some parameters of longitudinal river profiles: the case of the Ardenne (Belgium, NW Europe). Geomorphology, 24, 189-208.

Déruelle, B., Ngounouno, I., \& Demaiffe, D. (2007). The "Cameroon Hot Line” (CHL): a unique example of active alkaline intraplate structure in both oceanic and continental lithospheres. C. R. Geosci., 339, 589-600.

Djomeni, A. L., Ntamak-Nida, M. J., Mvondo Owono, F., Fowe Kwetche, A. L., Djomeni, Iboum Kissaaka, J. B., \& Mooh-Enougui, E. (2011). Soft-sediment deformation structures in Mid- Cretaceous to Mid-Tertiary deposits, Centre East of the Douala sub-basin, Cameroon: Preliminary results of the tectonic control. Syllabus Review, 2(3), 92-105.

Dufaure, J. J. (2007). L'analyse des formes structurales revisitée. Relations entre érosion différentielle, aplanissements et tectonique continentale », Géomorphologie: Relief, processus, environnement, 2/2007, mis en ligne le 01 juillet 2009. Retrieved from http://geomorphologie.revues.org/index1182.html

Dumont, J. F. (1986). Identification par télédétection de l'Accident de la Sanaga (Cameroun). Géodynamique, 1, 13-19, ORSTOM.

El Hamdouni, R., Irigaray, C., Fernandez, T., Chacón, J., \& Keller, E. A. (2007). Assessment of Relative Active Tectonics, Southwest Border of Sierra Nevada (Southern Spain). Geomorphology, 96, 150-173. https://doi.org/10.1016/j.geomorph.2007.08.004

Fekete, K., \& Vojtko, R. (2013). Neotectonic activity of the Pravno fault in the area of the Ziar Mts. Acta Geologica Slovaca, 5(2), 117-127.

Goldrick, G., \& Bishop, P. (1995). Differentiating the roles of lithology and uplift in steepening bedrock river long profiles: an example from Southeastern Australia. Journal of Geology, 103, 227-231.

Goren, L, Willett, S. D., Herman, F., \& Braun, J. (2014). Coupled numerical-analytical approach to landscape evolution modeling. Earth Surface Processes and Landforms, 39, 522-545. https://doi.org/10.1002/2014JF003079.

Guarnieri, P., \& Pirotta, C. (2008). The response of drainage basins to the late Quaternary tectonics in the Sicilian side of the Messina Strait (NE Sicily). Geomorphology, 95, 260-273.

Hack, J.T. (1973). Stream-profile analysis and stream-gradient index. Journal Research U.S. Geological Survey, 1, 421-429.

Horton, R. E. (1945). Erosional development of stream and their drainage basin, hydrogeological approach to quantitative morphology. Geological Society of America Bulletin, 56, 275-370. https://doi.org/10.1130/00167606(1945)56[275:EDOSAT]2.0.CO;2

Hurtrez, J. E., Lucazeau, F., Lavé, J., \& Avouac, J. P. (1999). Investigation of the relationships between basin morphology, tectonic uplift, and denudation from the study of an active fold belt in the Siwalik Hills, central Nepal. Journal of Geophysical Research: Solid Earth, 104, 12779-12796.

IRGM. (2006). Projet «sismicité du Cameroun» in Rapport d'activités 2006, pp.17-18.

Jacques, P. D., Salvador, E. D., Machado, R., Grohmann, C. H., \& Nummer, A. R. (2014). Application of morphometry in neotectonic studies at the eastern edge of the Paraná Basin, Santa Catarina State, Brazil. Geomorphology, 213, 13-23.

Kale, V. S., Sengupta, S., Achyuthan, H., \& Jaiswal, M. K. (2014). Tectonic controls upon Kaveri River drainage, cratonic Peninsular India: Inferences from longitudinal profiles, morphotectonic indices, hanging valleys and fluvial records. Geomorphology, 227, 153-165.

Keller, E. A., \& Pinter, N. (1996). Active tectonics: Earthquakes, Uplift and Landscape. Prentice Hall, New Jersey. 
Keller, E. A., \& Pinter, N. (2002). Active Tectonics: Earthquakes, Uplift, and Landscape (second edition). Englewood Cliffs. Prentice Hall, New Jersey, p. 362.

Kirby, E., \& Whipple, K. (2001). Quantifying differential rock-uplift rates via stream profile analysis. Geology, 29, 415-418.

Kossoni, A. (1992). Etude préliminaire du lac Ossa - Environnement, paléoenvironnement et sédimentologie. Mémoire de Maîtrise, Université de Yaoundé, 53 p.

Koum, S., Mvondo Owono, F., Ntamak-Nida, M. J., Njom, B., \& Belinga, R. (2013). Surrection relative pliopléistocène de la surface côtière de la marge sud du Rio del Rey (Cameroun) à partir de la géomorphologie quantitative sur Modèle Numérique de Terrain (MNT). Sciences, Technologies et Développement, 14, 59-69.

Koumetio, F. (2004). Contribution géophysique par la méthode gravimétrique à l'étude des structures profondes de la marge occidentale du craton du Congo dans la région de Kribi (Cameroun). Thèse de Doctorat $3^{\mathrm{e}}$ cycle. Université de Yaoundé I. 110 p.

Lahiri, S. K., \& Sinha, R. (2012). Tectonic controls on the morphodynamics of the Brahmaputra River system in the upper Assam valley, India. Geomorphology. 169-170, 74-85.

Langbein, W. B. (1964). Profiles of rivers of uniform discharge. United States Geological Survey Professional Paper 501 B, 119-122. https://doi.org/10.2475/ajs.262.6.782

Lasserre, M., \& Soba, D. (1979). Migmatisation d'âge Panafricain au sein des formations camerounaises appartenant à la zone mobile de l'Afrique Centrale. C. R. som. Séance Soc. Géol. France, 2, pp. 64-68.

Louis, P. (1970). Contribution géophysique a la connaissance du bassin du Lac Tchad. ORSTOM, Mémoire 42, Paris, France, 308 p.

Melosh, B. L., \& Keller, E. A. (2013). Effects of active folding and reverse faulting on stream channel evolution, Santa Barbara Fold Belt, California. Geomorphology, 186, 119-135. https://doi.org/10.1016/j.geomorph.2012.12.027

Moussango, I. A. P. (2003). Contribution à l'étude tectonique d'un secteur marginal du bassin atlantique à Edéa. Mémoire de D.E.A., Univ. De Yaoundé I, 100 p.

Mvondo, O. F. (2011). Surrection cénozoïque des marges passives de l'Ouest d'Afrique à partir de deux exemples: le plateau sud Namibien et la marge nord camerounaise. Th. Doct. Publiée, Univ. Rennes 1, p. 324.

Mvondo, O. F., Ntamak-Nida, M. J., Dauteuil, O., Guillocheau, F., \& Njom, B. (2016). Morphology and long-term landscape evolution of the South African plateau in South Namibia. Catena, 142, 47-65.

Ngako, V., Affaton, P., Nnage, J. M., \& Njanko, T. (2003). Evolution tectonique pan-africaine dans le Centre et le Sud Cameroun : Transpression et transtension durant les cisaillements senestres. Journal of African Earth Sciences, 36, 207-214. https://doi.org/10.1016/S0899-5362(03)00023-X

Ngako, V., Jegouzo, P., \& Nzenti, J. P. (1991). Le Cisaillement Centre Camerounais. Rôle structural et géodynamique dans l'orogenèse panafricaine. C. R. Acad. Sci. Paris, 313(2), 457-463.

Ngako, V., Njonfang, E., Tongwa Aka, F., Affaton, P., \& Metuk Nnange, J. (2006). The North-South Paleozoic to Quaternary trend of alkaline magmatism from Niger-Nigeria to Cameroon: Complex interaction between hotspots and Precambrian faults. Journal of African Earth Sciences, 45, 241-256. https://doi.org/10.1016/j.jafrearsci.2006.03.003

Ngangom. (1983). Étude tectonique du fossé crétacé de la Mbere et du Djerem, Sud Adamaoua, Cameroun. Bull. Soc. Elf Aquitaine, 7, 339-347.

Nguene, F. R., Tamfu, S. F., Loule, J. P., \& Ngassa, C. (1992). Palaeoenvironments of the Douala and Kribi-Campo sub-basins, in Cameroon, West Africa, in R. Curnelle, ed., Géologie Africaine, 1er Colloque de Stratigraphie et de paléogéographie des bassins sédimentaires Ouest-Africains, 2ème Colloque Africain de Micropaléontologie: Elf Aquitaine, 129-139.

Njiké Ngaha, P. R. (1984). Contribution à l'étude géologique, stratigraphique et structurale de la bordure du bassin atlantique du Cameroun. Thèse de Doctorat de 3è cycle, Univ. De Yaoundé, $130 \mathrm{p}$.

Norman, J. W. (1976). Photogeological fracture trace analysis as a subsurface exploration

Nsangou, N. M., Owona, S., Mvondo, O. F., Mpesse, J. E., Youmen, D., Lissom, J., \& Mvondo, O. J. (2017). Tectonics, lithology and climate controls of morphometric parameters of the Edea - Eseka region (SW Cameroon, Central Africa): Implications on equatorial rivers and landforms. Journal of African Earth 
Sciences, 138, 219-232. https://doi.org/10.1016/j.jafrearsci.2017.11.008

Ntepe, N., Aka, T., Ubangoh, R., Ateba, B., Nange, M. J., \& Hell, J. V. (2004). The July 2002 earthquake in the Kribi region: geological context and a preliminary evaluation of seismic risk in southwestern Cameroon. Journal of African Earth Sciences, 40, 163-172. https://doi.org/10.1016/j.jafrearsci.2004.09.002.

Oba, A. O. (2001). Stratigraphy of Sergipe-Alagoas (Brazil), Douala, Rio Muni, and Gabon (West Africa) sedimentary basins (Aptian-Albian interval): Columbia, S.C., Dep. Geol. Sci., Univ. South Carolina, 16 p.

Obata, M., \& Karato, S. (1995). Ultramafic pseudotachylites from the Balmuccia peridotite, Ivrea-Verbano zone, northen Italy. Tectonophysics, 242, 313-328.

Ohmori, H. (1993). Changes in the hypsometric curve through mountain building resulting from concurrent tectonics and denudation. Geomorphology, 8, 263-277.

Penaye, J., Toteu, S. F., Van Schumus, W. R., \& Nzenti, J. P. (1993). U-Pb and Sm-Nd preliminary geochronologic data on the Yaoundé series, Cameroon: re-interpretation of the granulitic rocks as the suture of a collision in the Centrafrican belt. C. R. Acad. Sci. Paris, 317(2), 789-794.

Ribolini, A. (2000). Relief distribution,morphology and Cenozoic differential uplift in the Argentera Massif (French-Italian Alps). Z. Geomorphology, 44, 363-378.

Roe, G. H., Montgomery, D. R., \& Hallet, B. (2002). Effects of orographic precipitation variations on the concavity of steady state river profiles. Geology, 30, 143-146.

Sarma, J. N., Acharjee, S., \& Murgante, G. (2013). Morphotectonic study of the Brahmaputra basin using geoinformatics. Geophysical Research Abstracts 15, EGU2013-14001.

Shandini, N. Y. (2005). Implication structurale des anomalies gravimétriques en bordure septentrionale du craton du Congo. Mémoire de D.E.A., Université de Yaoundé I -Cameroun, 53 p.

Sibson, R. H. (1975). Generation of Pseudotachylyte by Ancient Seismic Faulting. Geophysical Journal International, 43(3), 775-794. https://doi.org/10.1111/j.1365-246X.1975.tb06195.x

Siddiqui, N., Rahman, A. H. A., Sum, C. W., Mathew, M. J., \& Menier, D. (2014). Facies characteristics and static reservoir connectivity of some siliciclastic Tertiary outcrop successions in Bintulu and Miri, Sarawak, East Malaysia. Search and Discovery Article 51035, Proceeding of the International Conference and Exhibition of American Association of Petroleum Geologist (AAPG). Istanbul, Turkey.

Snyder, N. P., Whipple, K. X., Tucker, G. E., \& Merrits, D. J. (2000). Landscape response to tectonic forcing: DEM analysis of stream profiles in the Mendocino triple junction region, northern California. Geological Society of America Bulletin, 112(8), 1250-1263.

Soba, D. (1989). La série du Lom: étude géologique et géochronologique d'un bassin volcano-sédimentaire de la chaîne panafricaine à l'Est du Cameroun. Thèse de doctorat d'Etat, Université Pierre et Marie Curie, Paris 6, $198 \mathrm{p}$.

Strahler, A. N. (1952). Hypsometric (area-altitude) analysis of erosionnal topography. Geol. Soc. Am. Bull, 63, 1117-1142. https://doi.org/10.1130/0016-7606(1952)63[1117:HAAOET]2.0.CO;2

Swanson, M. T. (1988). Pseudotachylites-bering strike-slip duplex structures in the Forst Brittle Zone, S. Maine. J. Struct. Geol., 10, 813-828.

Tabot, C. T., Fairhead, J. D., Stuart, G. W., Ateba, B., \& Ntepe, N. (1992). Seismicity of the Cameroon Volcanic Line, 1982-1990. Tectonophysics, 212, 303-320.

Tamfu, S. F., Batupe, M., Pauken, R. J., \& Boatwright, D. C. (1995). Geological setting, stratigraphy and hydrocarbon habitat of the Douala Basin. Cameroon. Am. Assoc. petr. Geol. Bull, 79(13), 95 p.

Toteu, S. F., Van Schmuss, W. R., Penaye, J., \& Nyobe, J. B. (1994). U-Pb and Sm-Nd evidence for eburnean and panafrican high grade metamorphism in cratonic rocks of southern Cameroon. Res., 67, 321-347.

Ueda, T., Obata, M., Di Toro, G., Kanagawa, K., \& Ozawa, K. (2008). Mantle earthquakes frozen in mylonitized ultramafic pseudotachylytes of spinel-lherzolite facies. Geology, 36, 607-610. https://doi.org/10.1130/G24739A.1

Viveen, W., van Balen, R. T., Schoorl, J. M., Veldkamp, A., Temme, A. J. A. M., \& Vidal-Romani, J. R. (2012). Assessment of recent tectonic activity on the NW Iberian Atlantic Margin by means of geomorphic indices and field studies of the Lower Mino River Terraces. Tectonophysics, 544-545, 13-30. 
Yéné, A. J. Q., \& Poudjom, D. Y. H. (2001). Structure profonde de la ligne volcanique du Cameroun à partir des études gravimétriques. Abstracts, Faculty of Science, Macquarie University, Sydney Australia.

Zhang, W., Hayakawa, Y. S., \& Oguchi, T. (2011). DEM and GIS based morphometric and topographic-profile analyses of Danxia landforms. Geomorphometry organization, 121-124.

\section{Copyrights}

Copyright for this article is retained by the author(s), with first publication rights granted to the journal.

This is an open-access article distributed under the terms and conditions of the Creative Commons Attribution license (http://creativecommons.org/licenses/by/4.0/). 